\title{
Genome-enabled studies of anaerobic, nitrate-dependent iron oxidation in the chemolithoautotrophic bacterium Thiobacillus denitrificans
}

\author{
Harry R. Beller ${ }^{*}{ }^{\dagger}$, Peng Zhou ${ }^{1,2 \dagger}$, Tina C. Legler ${ }^{3}$, Anu Chakicherla ${ }^{3}$, Staci Kane $^{3}$, Tracy E. Letain $^{3}$ and $^{-}$ \\ Peggy A. O'Day ${ }^{2}$
}

'Earth Sciences Division, Lawrence Berkeley National Laboratory, Berkeley, CA, USA

${ }^{2}$ University of California, Merced, CA, USA

${ }^{3}$ Lawrence Livermore National Laboratory, Livermore, CA, USA

\section{Edited by:}

Aindrila Mukhopadhyay, Lawrence Berkeley National Berkeley, USA

\section{Reviewed by:}

Toivo Kallas, University of Wisconsin-Oshkosh, USA Jason Warren Cooley, University of Missouri, USA

\section{*Correspondence:}

Harry R. Beller, Earth Sciences Division, Lawrence Berkeley National Laboratory, 1 Cyclotron Road, MS 70A-3317, Berkeley, CA 94720, USA e-mail: hrbeller@lbl.gov

${ }^{\dagger}$ Harry R. Beller and Peng Zhou have contributed equally to this study.
Thiobacillus denitrificans is a chemolithoautotrophic bacterium capable of anaerobic, nitratedependent U(IV) and Fe(II) oxidation, both of which can strongly influence the long-term efficacy of in situ reductive immobilization of uranium in contaminated aquifers. We previously identified two $c$-type cytochromes involved in nitrate-dependent U(IV) oxidation in T. denitrificans and hypothesized that $c$-type cytochromes would also catalyze Fe(II) oxidation, as they have been found to play this role in anaerobic phototrophic Fe(II)-oxidizing bacteria. Here we report on efforts to identify genes associated with nitrate-dependent $\mathrm{Fe}$ (II) oxidation, namely (a) whole-genome transcriptional studies [using $\mathrm{FeCO}_{3}, \mathrm{Fe}^{2+}$, and $\mathrm{U}(\mathrm{IV})$ oxides as electron donors under denitrifying conditions], (b) Fe(II) oxidation assays performed with knockout mutants targeting primarily highly expressed or upregulated $c$-type cytochromes, and (c) random transposon-mutagenesis studies with screening for $\mathrm{Fe}(\mathrm{II})$ oxidation. Assays of mutants for 26 target genes, most of which were c-type cytochromes, indicated that none of the mutants tested were significantly defective in nitrate-dependent Fe(II) oxidation. The non-defective mutants included the $c_{1}$-cytochrome subunit of the cytochrome $b c_{1}$ complex (complex III), which has relevance to a previously proposed role for this complex in nitrate-dependent Fe(II) oxidation and to current concepts of reverse electron transfer. A transposon mutant with a disrupted gene associated with $\mathrm{NADH}$ :ubiquinone oxidoreductase (complex I) was $\sim 35 \%$ defective relative to the wild-type strain; this strain was similarly defective in nitrate reduction with thiosulfate as the electron donor. Overall, our results indicate that nitrate-dependent Fe(II) oxidation in T. denitrificans is not catalyzed by the same $c$-type cytochromes involved in $\mathrm{U}(\mathrm{IV})$ oxidation, nor have other $c$-type cytochromes yet been implicated in the process.

Keywords: iron oxidation, nitrate-dependent, anaerobic, Thiobacillus denitrificans, chemolithoautotrophic, reverse electron transfer

\section{INTRODUCTION}

In situ microbial reductive immobilization of radionuclides in aquifers is a remedial approach that has been the subject of considerable interest since the 1990s. The essence of this approach is that many radionuclides of concern are redox-active and are less soluble in their reduced form, and thus can be immobilized in aquifers via microbially mediated reduction under anaerobic conditions. For example, $\mathrm{U}(\mathrm{VI})$ in the form of $\mathrm{UO}_{2}^{2+}$ (aq) and its complexes is relatively water soluble, whereas the mineral uraninite $\left[\mathrm{UO}_{2}(\mathrm{~s})\right.$ or other amorphous or nanocrystalline $\mathrm{U}(\mathrm{IV})$-oxide phases], typically formed by $\mathrm{U}(\mathrm{VI})$-reducing bacteria (Lovley and Phillips, 1992b; Fredrickson et al., 2000), has very low solubility. A range of bacteria has been shown to be capable of direct microbial reduction of uranium, including Geobacter metallireducens, Shewanella oneidensis, Desulfovibrio desulfuricans, D. vulgaris, and many others (Lovley et al., 1991, 1993; Lovley and Phillips, 1992a,b). However, recent studies have suggested that microbially mediated, nitrate-dependent U(IV) oxidation under anaerobic conditions could complicate efforts at long-term reductive immobilization. Nitrate-dependent oxidation is of particular relevance because nitrate is a common co-contaminant with uranium at U.S. Department of Energy (DOE) sites (Riley and Zachara, 1992). Finneran et al. (2002) showed that nitrategrown, but not $\mathrm{Fe}(\mathrm{III})$-grown, cells of G. metallireducens carried out nitrate-dependent $\mathrm{U}(\mathrm{IV})$ oxidation in anaerobic cell suspensions amended with $\mathrm{UBr}_{4}$, a soluble form of U(IV). Beller (2005) showed that the widely distributed, chemolithoautotrophic bacterium $T$. denitrificans is capable of anaerobic, nitrate-dependent oxidative dissolution of synthetic and biogenic U(IV) oxides, such as uraninite. In addition to controlled cell suspension studies with bacteria such as G. metallireducens and T. denitrificans, there is field evidence indicating the real-world relevance of nitratedependent oxidative mobilization of uranium. Senko et al. (2002) observed nitrate-dependent uranium solubilization during a 
push-pull (i.e., single-well) field study. In this study, much of the uranium that was previously immobilized in the aquifer was re-mobilized over a period of 1-2 weeks after addition of nitrate to the groundwater; the bacterial species and biogeochemical mechanisms involved were not elucidated in that study.

Furthermore, nitrate-dependent Fe(II) oxidation appears to enhance U(IV) oxidation, as has been observed for G. metallireducens (Finneran et al., 2002), an isolate from DOE's FRC site (Senko et al., 2005a), and T. denitrificans (H. R. Beller, unpublished data). The reason for the enhancement of U(IV) oxidation in the presence of nitrate-dependent Fe(II) oxidation has not been definitively shown. However, there is a growing body of evidence that substantiates the ability of Fe(III)-(hydr)oxide solids in the presence of dissolved $\mathrm{Fe}^{2+}$ and nitrite to oxidize $\mathrm{UO}_{2}$ (s) to aqueous uranyl ( $\mathrm{U}^{\mathrm{VI}} \mathrm{O}_{2}^{2+}$; Finneran et al., 2002; Sani et al., 2005; Senko et al., 2005a,b, 2007; Wan et al., 2005; Ginder-Vogel et al., 2006; Tokunaga et al., 2008). For example, Senko et al. (2005a) reported $\mathrm{UO}_{2}(\mathrm{~s})$ oxidation in the presence of $\mathrm{Fe}(\mathrm{III})$ minerals, including ferrihydrite $\left[\mathrm{Fe}(\mathrm{OH})_{3}(\mathrm{~s})\right]$ and a poorly crystalline $\mathrm{Fe}(\mathrm{III})$ solid resulting from the abiotic oxidation of $\mathrm{Fe}(\mathrm{II})$ by nitrite.

Microbial $\mathrm{Fe}(\mathrm{II})$ oxidation, including anaerobic, nitratedependent $\mathrm{Fe}$ (II) oxidation, has been reviewed by a number of authors in recent years (Weber et al., 2006a; Bird et al., 2011; Hedrich et al., 2011; Roden, 2012; Ilbert and Bonnefoy, 2013) and will not be covered in detail here. The initial report of nitrate-dependent Fe(II) oxidation by Straub et al. (1996) included the observation that $T$. denitrificans could couple denitrification to anaerobic oxidation of ferrous iron in common minerals, such as FeS. Known representatives of the anaerobic, nitratedependent $\mathrm{Fe}(\mathrm{II})$-oxidizing bacteria fall within several classes of the proteobacteria, in particular the $\beta$-proteobacteria (e.g., T. denitrificans, Pseudogulbenkiania sp. 2002, Azospira oryzae strain PS, Aquabacterium sp BrG2, Acidovorax sp BrG1, and Acidovorax ebreus TPSY), but also the $\alpha$-proteobacteria (Paracoccus ferrooxidans strain BDN-1), $\gamma$-proteobacteria (e.g., Thermomonas sp. BrG3), and the $\delta$-proteobacteria ( $G$. metallireducens; Hedrich et al., 2011). Very few of the studied anaerobic, nitratedependent $\mathrm{Fe}(\mathrm{II})$-oxidizing microbial isolates are able to carry out this activity under strictly autotrophic growth conditions; these include Pseudogulbenkiania sp. 2002 (Weber et al., 2006b, 2009) and the hyperthermophilic archaeum Ferroglobus placidus (Hafenbradl et al., 1996). Although T. denitrificans, an obligate chemolithoautotrophic bacterium, was reported to carry out nitrate-dependent Fe(II) oxidation (Straub et al., 1996), energy conservation and growth were not demonstrated. As has been noted previously (Weber et al., 2006a; Picardal, 2012), many of the nitrate-dependent, $\mathrm{Fe}$ (II)-oxidizing cultures described to date are organotrophic (or at least mixotrophic) rather than autotrophic, and the use of organic compounds (such as acetate) as carbon sources and electron donors complicates the interpretation of their physiology and metabolism. In this sense, the lithoautotroph $T$. denitrificans represents a more simple experimental system for the study of nitrate-dependent Fe(II) oxidation.

Among anaerobic, Fe(II)-oxidizing bacteria, the primary enzymes associated with catalysis of $\mathrm{Fe}$ (II) oxidation have only been identified in anoxygenic, phototrophic bacteria, not in any nitrate-reducing, $\mathrm{Fe}$ (II)-oxidizing strains to date (Bird et al., 2011;
Ilbert and Bonnefoy, 2013). In the phototroph Rhodopseudomonas palustris TIE-1, the pioABC operon has been demonstrated to be essential to Fe(II) oxidation (Jiao and Newman, 2007). The proteins encoded by pioABC include PioA, a periplasmic, decaheme, $c$-type cytochrome, $\mathrm{PioB}$, an outer-membrane (OM) porin, and PioC, a periplasmic high-potential iron-sulfur protein (HiPIP; Jiao and Newman, 2007). Notably, PioA and PioB share homology with MtrA and MtrB, respectively, in Shewanella oneidensis MR-1, which have been associated with Fe(III) reduction in that bacterium. In the phototroph Rhodobacter strain SW2, the foxEYZ operon has been linked to Fe(II) oxidation by heterologous expression in the related and genetically tractable Rhodobacter capsulatus SB1003 (Croal etal., 2007). The proteins encoded by foxEYZ include FoxE, a diheme $c$-type cytochrome (Saraiva et al., 2012), FoxY, a predicted redox cofactor pyrroloquinoline quinone, and FoxZ, a predicted inner-membrane transport protein. Although the PioABC and FoxEYZ systems are not homologous, both contain $c$-type cytochromes as essential components. Considering the thermodynamic constraints on compounds that could serve as physiological electron acceptors for Fe(II) oxidation, the involvement of $c$-type cytochromes is not surprising. To illustrate, the reduction potential for the $\mathrm{Fe}(\mathrm{OH})_{3} / \mathrm{FeCO}_{3}$ couple $(\sim 0.2 \mathrm{~V}$; Hedrich et al., 2011) is high relative to common electron carriers in the cell, such as ferredoxin, $\mathrm{NAD}^{+}, \mathrm{FAD}$, menaquinone, and ubiquinone, which collectively fall in the reduction potential range of -0.4 to $+0.11 \mathrm{~V}$ (Thauer et al., 1977). In fact, $c$-type and $a$-type cytochromes are among the few common electron carriers with sufficiently high reduction potentials to serve as electron acceptors for $\mathrm{Fe}(\mathrm{II})$. Another reason for $c$-type cytochromes to be candidates for nitrate-dependent $\mathrm{Fe}(\mathrm{II})$ oxidation in T. denitrificans is that two diheme, $c$-type cytochromes were previously shown to be associated with nitrate-dependent $U(I V)$ oxidation in that species (Beller et al., 2009).

In this article, we explore anaerobic, nitrate-dependent Fe(II) oxidation in the widespread, obligately chemolithoautotrophic bacterium T. denitrificans, which has also been shown to be capable of anaerobic, nitrate-dependent U(IV) oxidation. Almost nothing is known about the underlying biochemistry and genetics of nitrate-dependent $\mathrm{Fe}$ (II) and $\mathrm{U}(\mathrm{IV})$ oxidation in any bacteria or archaea. Inasmuch as $T$. denitrificans already has a sequenced genome (Beller et al., 2006a), genetic system (Letain et al., 2007; Beller et al., 2012), and custom-designed gene expression microarrays (Beller etal., 2006b), it served as a good subject for genome-enabled studies. We report on whole-genome transcriptional studies of $T$. denitrificans comparing gene expression under nitrate-dependent $\mathrm{Fe}(\mathrm{II})-, \mathrm{U}(\mathrm{IV})$-, and thiosulfate (control)-oxidizing conditions, targeted gene knockouts based on these results (reverse genetics), as well as random transposon mutagenesis studies (forward genetics). To our knowledge, this is the most extensive investigation to date of enzymes involved in anaerobic, nitrate-dependent $\mathrm{Fe}(\mathrm{II})$ oxidation.

\section{MATERIALS AND METHODS ANALYTICAL METHODS}

Thiosulfate, sulfate, nitrate, and nitrite concentrations were measured by ion chromatography (IC) using a Model DX 500 IC (Dionex Corporation, Sunnyvale, CA, USA) or a Model 
ICS-2000 IC (Dionex) with micromembrane suppression and electrochemical conductivity detection (Beller, 2005; Han et al., 2010). Quantification relied on external standards using a 3-point calibration.

The microplate assay used for Fe(II) analysis was described previously by Beller et al. (2013). Microplates (96-well) that had been stored in an anaerobic glove box for at least one day were amended with $90 \mu \mathrm{L}$ of $1 \mathrm{~N} \mathrm{HCl}$, and a $10 \mu \mathrm{L}$ cell suspension sample was added to the $\mathrm{HCl}$ immediately after sampling. Then, $100 \mu \mathrm{L}$ of Ferrozine solution ( $1 \mathrm{~g} / \mathrm{L}$ Ferrozine, $500 \mathrm{~g} / \mathrm{L}$ ammonium acetate) was added to the acidified sample. After a 10-min incubation, absorbance at $570 \mathrm{~nm}$ was measured using a Model 550 microplate reader (Bio-Rad, Hercules, CA, USA). Fe(II) standards $(0.2,0.5,1$, and $2 \mathrm{mM}$ ferrous ammonium sulfate hexahydrate in $1 \mathrm{~N} \mathrm{HCl}$ ) were included on each microtiter plate.

Highly purified water (18 $\mathrm{M} \Omega$ resistance) obtained from a Milli-Q Biocel system (Millipore, Bedford, MA, USA) was used to prepare all aqueous solutions described in this article.

\section{WHOLE-CELL SUSPENSION ASSAYS FOR NITRATE-DEPENDENT Fe(II) OXIDATION}

In vivo assays of nitrate-dependent $\mathrm{Fe}$ (II) oxidation by wild-type T. denitrificans (ATCC strain 25259, obtained from the American type culture collection) and various mutant strains were conducted under strictly anaerobic conditions in an anaerobic glove box. Cells (typically $400 \mathrm{~mL}$ ) were cultivated at $30^{\circ} \mathrm{C}$ as described previously (Beller, 2005) with growth medium that contained $20 \mathrm{mM}$ thiosulfate, $20 \mathrm{mM}$ nitrate, $30 \mathrm{mM}$ bicarbonate ( $\mathrm{pH} \sim 7$ ), and kanamycin and/or gentamicin (as appropriate). Cells were harvested anaerobically by centrifugation $(13,400 \times g$, $20^{\circ} \mathrm{C}, 15 \mathrm{~min}$ ), washed by resuspension in $200 \mathrm{~mL}$ of basal anaerobic buffer described previously [Beller, 2005; $\mathrm{NH}_{4} \mathrm{Cl}(18.7 \mathrm{mM})$, $\left.\mathrm{KH}_{2} \mathrm{PO}_{4}(1.5 \mathrm{mM}), \mathrm{NaHCO}_{3}(30 \mathrm{mM}), \mathrm{MgSO}_{4}(3.25 \mathrm{mM})\right]$, centrifuged again $\left(13,400 \times \mathrm{g}, 20^{\circ} \mathrm{C}, 10 \mathrm{~min}\right)$, and resuspended in a volume of basal anaerobic buffer (typically, $\sim 2 \mathrm{~mL}$ ) to result in an $\mathrm{OD}_{600} \approx 8$. (An $\mathrm{OD}_{600}$ value of 1 corresponds to approximately $9 \times 10^{8}$ cells per $\mathrm{mL}$ or $0.19 \mathrm{mg}$ protein per $\mathrm{mL}$.) Cell suspensions were mixed with an equal volume of anaerobic, filtered assay solution, which consisted of basal buffer amended with $3 \mathrm{mM} \mathrm{FeSO}_{4}, 2 \mathrm{mM} \mathrm{KNO}_{3}$, and $20 \mathrm{mM}$ trisodium nitrilotriacetate (NTA). The NTA was added to prevent encrustation of Fe(III) precipitates on cells (Jiao and Newman, 2007). The assays $(200 \mu \mathrm{L}$ total volume) were performed in 96-well microplates under static conditions. No-nitrate, no-cell, and no-iron controls were performed in a similar manner, except that $\mathrm{KNO}_{3}$, cells, or $\mathrm{FeSO}_{4}$ were replaced with anaerobic reagent water. Concentrations of $\mathrm{Fe}(\mathrm{II})$, nitrate, and nitrite were measured at $0,1,2.5$, and $5 \mathrm{~h}$ by the Ferrozine microplate and IC methods described above. Fe(II) oxidation assays were performed with biological triplicates as well as analytical triplicates for the microplate assays.

For selected strains, positive controls to assess batch-specific denitrification activity of $T$. denitrificans cells were carried out in the growth medium (i.e., with thiosulfate as the electron donor) and received the same inoculum (in terms of concentration of cells) as cultures assayed for Fe(II) oxidation (Beller, 2005).

Abiotic tests of nitrite redox interactions with $\mathrm{Fe}(\mathrm{II})$ were conducted as described above except that $\mathrm{KNO}_{3}$ was replaced with
$\mathrm{NaNO}_{2}$ at a final concentration of $150 \mu \mathrm{M}$ and no cells were added.

\section{TESTS FOR GROWTH OF T. denitrificans USING Fe(II) AS THE ELECTRON DONOR}

Growth of T. denitrificans on Fe(II)-nitrate medium was tested anaerobically under a $90 \% \mathrm{~N}_{2}-10 \% \mathrm{CO}_{2}$ atmosphere at $30^{\circ} \mathrm{C}$. The differences between the medium used for these experiments and standard growth medium (Beller, 2005) were as follows: $10 \mathrm{mM}$ $\mathrm{FeSO}_{4}$ replaced $20 \mathrm{mM}$ thiosulfate as the electron donor, and the concentration of $\mathrm{KNO}_{3}$ was lowered from 20 to $2.5 \mathrm{mM}$. The inoculum was $10 \%(\mathrm{vol} / \mathrm{vol})$ thiosulfate-grown cells that were washed with growth medium lacking thiosulfate and nitrate. Three biological replicates were tested along with controls lacking either $\mathrm{FeSO}_{4}$ or $\mathrm{KNO}_{3}$. Consumption of $\mathrm{Fe}(\mathrm{II})$ was measured with the Ferrozine assay described above and protein concentration was determined with a Quick Start Bradford Protein Assay Kit (Bio-Rad).

\section{EXPOSURE CONDITIONS FOR GENE EXPRESSION MICROARRAYS}

To represent gene expression under denitrifying conditions with various electron donors, wild-type T. denitrificans was cultivated at $30^{\circ} \mathrm{C}$ under strictly anaerobic conditions as described previously (Beller, 2005) with growth medium that contained $20 \mathrm{mM}$ thiosulfate, $20 \mathrm{mM}$ nitrate, and $30 \mathrm{mM}$ bicarbonate ( $\mathrm{pH} \sim 7$ ). For exposure immediately before harvesting of RNA, 1,200 mL of cells in late exponential phase $\left(1 \times 10^{8}\right.$ to $2 \times 10^{8}$ cells $\left./ \mathrm{mL}\right)$ were harvested anaerobically by centrifugation $\left(13,400 \times g, 15^{\circ} \mathrm{C}\right.$, $10 \mathrm{~min}$ ), washed by resuspension in $75 \mathrm{~mL}$ of basal anaerobic buffer described previously (Beller, 2005), centrifuged again $\left(13,400 \times g, 15^{\circ} \mathrm{C}, 5 \mathrm{~min}\right)$, resuspended in $4 \mathrm{~mL}$ of basal anaerobic buffer, and $1 \mathrm{~mL}$ of this cell suspension (containing an average of $4.8 \mathrm{mg}$ protein) was added to 4 or $9 \mathrm{~mL}$ of buffer amended with a variety of solutions, described below.

The range of exposure conditions is listed in Table 1. With the exception of aerobic, thiosulfate-oxidizing conditions (Group IV; previously described by Beller et al., 2006b), all incubations were under anaerobic, denitrifying conditions in serum vials sealed with butyl rubber stoppers. All materials for manipulating and containing samples were allowed to degas in the anaerobic glove box for at least 2 days. Three or four biological replicates were tested for each condition. For thiosulfate-oxidizing, denitrifying conditions (Groups III, VII, and VIII; Table 1), incubations were performed in $10-\mathrm{mL}$ volumes with $20 \mathrm{mM}$ thiosulfate and $20 \mathrm{mM}$ nitrate for $40 \mathrm{~min}$ (Groups VII and VIII) or $60 \mathrm{~min}$ (Group III). (The 75-mL cell-washing step described above was not used for thiosulfate-oxidizing cells, since they were harvested after growth under the same conditions). For anaerobic incubations conducted in the absence of $\mathrm{H}_{2}$ (Groups I and VIII; Table 1), sealed serum bottles were vacuum-gassed three times with an anaerobic mixture of $90 \% \mathrm{~N}_{2}-10 \% \mathrm{CO}_{2}$, whereas incubations with $\mathrm{H}_{2}$ (Groups II, III, V, VI, and VII; Table 1) had a mixture of approximately $85 \% \mathrm{~N}_{2}-10 \% \mathrm{CO}_{2}-5 \% \mathrm{H}_{2}$ in the headspace. Incubation conditions listed with $\mathrm{FeCO}_{3}$ (Groups I and $\mathrm{V}$ ) contained $3 \mathrm{mM}$ nitrate and $3 \mathrm{mmol} / \mathrm{L} \mathrm{Fe}(\mathrm{II})$ precipitate; the precipitate was formed $1-2 \mathrm{~h}$ before incubation 
Table 1 | Exposure conditions for T. denitrificans cells used for gene expression microrrays ${ }^{a}$.

\begin{tabular}{|c|c|c|c|c|}
\hline Group & Electron donor & $\begin{array}{l}\text { Electron } \\
\text { acceptor }\end{array}$ & pH buffer ${ }^{b}$ & $\begin{array}{l}\text { GEO }^{c} \text { accession } \\
\text { number }\end{array}$ \\
\hline IV & Thiosulfate, no $\mathrm{H}_{2}$ & $\mathrm{O}_{2}$ & Bicarbonate & $\begin{array}{l}\text { GSM119288, } \\
\text { GSM120794, } \\
\text { GSM120797 }\end{array}$ \\
\hline VIII & Thiosulfate, no $\mathrm{H}_{2}$ & Nitrate & Bicarbonate & $\begin{array}{l}\text { GSM120793, } \\
\text { GSM120795, } \\
\text { GSM120796 }\end{array}$ \\
\hline III & Thiosulfate, $\mathrm{H}_{2}$ & Nitrate & Bicarbonate & GSM1128769-71 \\
\hline VII & Thiosulfate, $\mathrm{H}_{2}$ & Nitrate & Bicarbonate & GSM1128782-4 \\
\hline ॥ & $\mathrm{Fe}^{2+}$ (aq.), $\mathrm{H}_{2}$ & Nitrate & MOPS & GSM1128766-8 \\
\hline । & $\mathrm{FeCO}_{3}, \mathrm{no} \mathrm{H}_{2}$ & Nitrate & Bicarbonate & GSM1128763-5 \\
\hline V & $\mathrm{FeCO}_{3}, \mathrm{H}_{2}$ & Nitrate & Bicarbonate & GSM1128775-7 \\
\hline VI & $\mathrm{UO}_{2}, \mathrm{H}_{2}$ & Nitrate & Bicarbonate & GSM1128778-81 \\
\hline
\end{tabular}

a See text for details. All experiments other than Group IV were conducted with one of three large batches of cells; each batch of cells was split into up to four smaller batches that were exposed to various electron donors (in triplicate).

${ }^{b}$ Buffers also contained $1.5 \mathrm{mM}$ phosphate, except for Group IV, which contained $70 \mathrm{mM}$ phosphate (Beller etal., 2006b).

${ }^{\mathrm{C}}$ GEO, Gene Expression Omnibus.

by adding $\mathrm{FeSO}_{4}$ to the basal resuspension medium (which contained $30 \mathrm{mM} \mathrm{HCO}_{3}^{-}$) without cells. Equilibrium modeling of the initial assay mixture using TOUGHREACT (Xu et al., 2011) with a modified MinteqA2 v.4 database (U.S. Environmental Protection Agency, 1999) using a revised solubility constant for siderite $\left(\mathrm{FeCO}_{3}\right.$; Preis and Gamsjager, 2002) indicated that $\mathrm{FeCO}_{3}$ would constitute $>99 \%$ of the initial $\mathrm{Fe}$-containing precipitates. Incubation conditions with mostly dissolved $\mathrm{Fe}(\mathrm{II})\left(\mathrm{Fe}^{2+}\right.$; Group II) contained $3 \mathrm{mM}$ nitrate and $3 \mathrm{mM} \mathrm{Fe}(\mathrm{II})$, but were conducted in a $20 \mathrm{mM}$-MOPS [3-(N-morpholino)propanesulfonic acid] buffered medium rather than $30 \mathrm{mM} \mathrm{HCO}_{3}^{-}$-buffered medium to preclude precipitation with carbonate. Finally, incubation with U(IV) oxides (Group VI) included $3 \mathrm{mM}$ nitrate and either $\sim 0.225 \mathrm{mmol} / \mathrm{L}$ biogenic uraninite (described previously; Beller, 2005; three biological replicates) or $\sim 2 \mathrm{mmol} / \mathrm{L}$ synthetic $\mathrm{U}(\mathrm{IV})$ oxide slurry (described previously; Beller, 2005; one biological replicate]. All incubations with $\mathrm{Fe}(\mathrm{II})$ or $\mathrm{U}(\mathrm{IV})$ were carried out in a $5-\mathrm{mL}$ liquid volume for $\sim 200 \mathrm{~min}$. Chemical controls (lacking T. denitrificans cells) were conducted for $\mathrm{Fe}(\mathrm{II})$ and U(IV) experiments to confirm that oxidation was microbially mediated.

The relevant metabolic activity [e.g., as applicable, thiosulfate oxidation to sulfate, nitrate reduction, $\mathrm{Fe}(\mathrm{II})$ oxidation to $\mathrm{Fe}(\mathrm{III}), \mathrm{U}(\mathrm{IV})$ oxidation to $\mathrm{U}(\mathrm{VI})]$ was confirmed in all anaerobic and aerobic suspensions by sampling each culture twice: immediately upon resuspension and immediately before harvesting for RNA. Previous experiments indicated that the sampling times used for the various conditions were appropriate for capturing ongoing metabolic activity. Analytical methods are described above.

\section{RNA EXTRACTION FOR MICROARRAYS}

Immediately after exposures (i.e., within $15 \mathrm{~s}$ ), two volumes of RNAprotect (Qiagen, Valencia, CA, USA) were added to each culture. Samples were incubated at room temperature for $12 \mathrm{~min}$, split in half, and centrifuged at 4,000 rpm for $10 \mathrm{~min}$. The supernatant was decanted and the pellet was stored at $-20^{\circ} \mathrm{C}$ until extraction. RNA extraction was carried out with a MasterPure Complete DNA and RNA Purification Kit (Epicentre Biotechnologies, Madison, WI, USA) using a modified protocol. Briefly, the frozen RNA pellet was removed from frozen storage, thawed on ice, and resuspended in $100 \mu \mathrm{L} 5 \mathrm{mM}$ EDTA (ethylenediaminetetraacetic acid) to remove iron from cells exposed to iron. After resuspension of the pellet, $300 \mu \mathrm{L}$ of lysis solution containing $112 \mu \mathrm{g}$ proteinase $\mathrm{K}$ was added to the cell pellet and the sample was incubated at $65^{\circ} \mathrm{C}$ for $20-25 \mathrm{~min}$. The sample was placed on ice for 3-5 min and $200 \mu \mathrm{L}$ of MPC solution was added to precipitate protein. The supernatant was recovered after centrifugation at $>10,000 \times g$, at $4^{\circ} \mathrm{C}$ for $10 \mathrm{~min}$. Nucleic acid was subsequently precipitated from the supernatant after addition of $500 \mu \mathrm{L} 99 \%$ isopropanol and centrifugation at $>10,000 \times \mathrm{g}$, at $4^{\circ} \mathrm{C}$ for $10 \mathrm{~min}$. The pellet was treated with DNase I for $20 \mathrm{~min}$ at $37^{\circ} \mathrm{C}$. To this sample was added $200 \mu \mathrm{L}$ each of $2 \times \mathrm{T} \& \mathrm{C}$ lysis solution and MPC solution with vortexing after each addition. The samples were placed on ice for 3-5 min and centrifuged at $>10,000 \times g$, at $4^{\circ} \mathrm{C}$ for $10 \mathrm{~min}$. RNA in the supernatant was recovered by isopropanol precipitation as described. The RNA pellet was washed twice with $75 \%$ ethanol, dried briefly, suspended in water, and stored at $-80^{\circ} \mathrm{C}$ until cDNA synthesis. Aliquots were analyzed with a Bioanalyzer (Agilent), which indicated minimal degradation and concentrations ranging from 310 to $2,000 \mathrm{ng} / \mu \mathrm{L}$. DNA absorbance $260 / 280$ ratios ranged from 1.7 to 2.1 .

\section{PREPARATION OF LABELED cDNA FOR MICROARRAYS AND MICROARRAY HYBRIDIZATION AND SCANNING}

CDNA production and labeling, as well as array hybridization and scanning were performed as described previously (Beller et al., 2006b).

\section{MICROARRAY DATA ANALYSIS}

Investigation of reproducible differences between treatments was performed using the Bioconductor R software package. Data were processed using quantile normalization (Bolstad et al., 2003) and background correction was performed using the RMA (Robust Multi-array Average) method. Data were visualized with scatterplots (volcano plots) that plotted the log odds of differential expression versus no differential expression (B-statistic) on the $y$-axis versus the $\log _{2}$-fold change between the two experimental conditions ( $M$ value) on the $x$-axis. A threshold of significance was set at $P \leq 0.0001$ (i.e., this was the threshold used for determining differential expression). Volcano plots were generated with the "volcanoplot" function in the Limma package (Linear Models for Microarray Data; Smyth, 2005). Intensities were adjusted to have the same interquartile range. A linear model fit was determined for each gene using the Limma package and lists of genes with the most evidence of differential expression were obtained. 
The microarray design for T. denitrificans ATCC 25259 has been described elsewhere (Beller etal., 2006b) and is documented in the NCBI GEO database (accession number GPL 3977).

\section{CONSTRUCTION OF MUTANT STRAINS WITH TARGETED MUTATIONS}

In some cases (see Table 2), targeted mutations were kanamycin (kan)insertion mutations constructed in $T$. denitrificans as described previously (Letain et al., 2007; Beller et al., 2009, 2012). However, for the majority of the targeted mutations, a more rapid, single-step gene replacement approach was performed using a modified version of a technique described elsewhere (Murphy etal., 2000; Lloyd et al., 2003). To illustrate, we describe below how this technique was used to replace the Tbd_0055 gene by homologous recombination. After genomic DNA was extracted using the MasterPure DNA purification kit (Epicentre Biotechnologies), it was used as the template for three primary PCRs performed using Taq DNA polymerase (Qiagen; Q-Solution was used for reactions involving T. denitrificans genomic DNA):

(i) primers Tbd_0055-1 and Tbd_0055-2 (Table 3) were used to amplify the upstream sequence of the Tbd_0055 gene using the following conditions: $94^{\circ} \mathrm{C}$ for $30 \mathrm{~s}$, followed by 35 cycles of $94^{\circ} \mathrm{C}$ for $30 \mathrm{~s}, 55^{\circ} \mathrm{C}$ for $30 \mathrm{~s}$, and $72^{\circ} \mathrm{C}$ for $1 \mathrm{~min}$ and a final extension at $72^{\circ} \mathrm{C}$ for $10 \mathrm{~min}$. The amplicon was purified with QIAquick PCR Purification Kit (Qiagen) and digested with EcoRI (New England Biolabs, Ipswich, MA, USA), which was introduced with Primer Tbd_0055-2.

(ii) primers Tbd_0055-5 and Tbd_0055-6 (Table 3) were used to amplify the downstream sequence of the Tbd_0055 gene (using the same PCR conditions listed above) and the amplicon was purified with QIAquick PCR Purification Kit (Qiagen) and was digested with XbaI (New England Biolabs), which was introduced with Primer Tbd_0055-5;

(iii) primer KO3-EcoRI (which introduced EcoRI) and primer KO4 (Table 3) were used to amplify the $\mathrm{Kan}^{\mathrm{R}}$ cassette, with the EZ-Tn5 $<$ KAN-2 > Tnp Transposome serving as the template, and the product was purified and digested with EcoRI and XbaI.

The three digested PCR products were ligated using a FastLink DNA Ligation Kit (Epicentre Biotechnologies). The ligation product was used as a template for recombinant PCR, which was carried out with Primers Tbd_0055-1 and Tbd_0055-6 using the following conditions: $94^{\circ} \mathrm{C}$ for $30 \mathrm{~s}$, followed by 35 cycles of $94^{\circ} \mathrm{C}$ for $30 \mathrm{~s}, 55^{\circ} \mathrm{C}$ for $30 \mathrm{~s}$, and $72^{\circ} \mathrm{C}$ for $3 \mathrm{~min}$ and a final extension at $72^{\circ} \mathrm{C}$ for $10 \mathrm{~min}$. The recombinant PCR product was purified and used for transformation of $T$. denitrificans, which was performed with $\sim 100 \mathrm{ng}$ of DNA according to methods described previously (Letain et al., 2007). After electroporation, cells were spread on agar plates containing $50 \mu \mathrm{g} / \mathrm{mL}$ kanamycin and cultured under denitrifying conditions at $30^{\circ} \mathrm{C}$ in an anaerobic glove box. Mutant colonies were cultured with growth medium containing $50 \mu \mathrm{g} / \mathrm{mL}$ kanamycin. The gene replacement was confirmed by PCR with primers Tbd_0055-1 and Tbd_0055-6 using the genomic DNA from the mutant.

\section{CONSTRUCTION OF MUTANT STRAINS BY RANDOM TRANSPOSON MUTAGENESIS}

Competent cells of $T$. denitrificans were prepared as described elsewhere (Letain etal., 2007). One $\mu \mathrm{L}$ EZ-Tn5 < KAN$2>$ Tnp transposome (Epicentre Biotechnologies) was mixed with $50 \mu \mathrm{L}$ chilled competent cells. Electroporation was performed according to previously described methods (Letain et al., 2007), with the modification that $15 \mathrm{kV} / \mathrm{cm}$ was chosen as the electroporation voltage rather than $12.5 \mathrm{kV} / \mathrm{cm}$. After electroporation, $1 \mathrm{~mL}$ pre-warmed growth medium was added to the cuvette to resuspend cells and the cell suspension was transferred into a 1.5-mL microcentrifuge tube. After a 1$\mathrm{h}$ recovery, kanamycin was added, and the cells were plated on solid medium containing $50 \mu \mathrm{g} / \mathrm{mL}$ kanamycin and incubated at $30^{\circ} \mathrm{C}$ in an anaerobic glove box. Negative controls included blank competent cells, blank medium, or a blank plate.

\section{SCREENING FOR TRANSPOSON MUTANTS DEFECTIVE IN Fe(II) OXIDATION}

Colonies from plates containing kanamycin were picked into 96well plates with $240 \mu \mathrm{L}$ thiosulfate-limited medium in each well (the concentration of thiosulfate was $10 \mathrm{mM}$ rather than the $20 \mathrm{mM}$ used in growth medium). After a 72-h incubation in sealed containers in the anaerobic glove box, the $\mathrm{OD}_{600}$ values of the 96-well plates were measured. $100 \mu \mathrm{L}$ of cell culture was transferred to another 96-well plate containing $100 \mu \mathrm{L} 3 \mathrm{mM}$ $\mathrm{Fe}(\mathrm{II})$. The initial $\mathrm{Fe}(\mathrm{II})$ concentration was determined spectrophotometrically using the Ferrozine assay described above. The 96-well plates were sealed and incubated at $30^{\circ} \mathrm{C}$ in the anaerobic glove box for 8 days, after which the $\mathrm{Fe}(\mathrm{II})$ concentration of the plates was again measured using the Ferrozine assay.

The mutants that displayed defective $\mathrm{Fe}(\mathrm{II})$ oxidation were cultured in regular (thiosulfate-nitrate) growth medium containing $50 \mu \mathrm{g} / \mathrm{mL}$ kanamycin and whole-cell suspension assays were performed as described above. Genomic DNA of the confirmed defective mutants as well as pUC19 plasmid DNA was extracted as described above and digested with SalI and XbaI (New England Biolabs). The digested genomic DNA and pUC19 plasmid DNA were purified with a QIAquick PCR Purification Kit (Qiagen) and ligated using a Fast-Link DNA Ligation Kit (Epicentre Biotechnologies) following the manufacturer's protocols. $1 \mu \mathrm{L}$ of the ligation product was used for electroporation of One Shot TOP10 Electrocomp E. coli cells (Table 2) followed by recovery in SOC medium (Invitrogen, Grand Island, NY, USA) according to the manufacturer's instructions, and spread on lysogeny broth (LB) agar plates containing $50 \mu \mathrm{g} / \mathrm{mL}$ kanamycin. The kanamycin-resistant colonies were cultured in liquid LB medium, followed by plasmid extraction using a QIAprep Spin Miniprep Kit (Qiagen). The location of the insertion was determined by sequencing the plasmid with the KAN-2 FP-1 Forward Primer and KAN-2 RP-1 Reverse Primer, which were provided with the EZ-Tn5 $<$ KAN-2 $>$ Tnp Transposome Kit. DNA sequencing was performed by the DNA Sequencing Facility at the University of California, Berkeley (Berkeley, CA, USA). 
Table 2 | Strains, plasmids, and transposons used in this study.

\section{Strain, plasmid, or}

transposon

\section{Strains}

Escherichia coli TOP10

\section{Thiobacillus denitrificans}

ATCC 25259

Tbd_0055 mutant

Tbd_0070 mutant

Tbd_0094 mutant

Tbd_0128-Tbd_0129 mutant $^{\mathrm{a}}$

Tbd_0137 mutant $^{\mathrm{b}}$

Tbd_0137-Tbd_0139 mutant $^{\mathrm{a}}$

Tbd_0146 mutant ${ }^{b}$

Tbd_0187 mutant $^{b}$

Tbd_0146, Tbd_0187 mutant $^{b}$

Tbd_0341 mutant

Tbd_0723 mutant $^{\text {b }}$

Tbd_0820 mutant

Tbd_0822 mutant

Tbd_1357 mutant

Tbd_1398 mutant $^{\text {b }}$

Tbd_1741 mutant

Tbd_1831 mutant

Tbd_1948 mutant $^{\text {b }}$

Tbd_2026-Tbd_2027

mutant $^{\mathrm{a}}$

Tbd_2060 mutant

Tbd_2181 mutant

Tbd_2545 mutant

Tbd_2628 mutant

Tbd_2726 mutant $^{\text {b }}$

Tbd_1145 mutant

\section{Plasmids}

\section{pUC19}

pUC19-Kan-P137A11

pUC19-Tbd0187

pUC19-Tbd0187::gent

pUC19-Tbd0146::kan

pUC19-Tbd0137

pUC19-Tbd0137::kan

\section{Genotype or markers;}

characteristics and uses

$\mathrm{F}^{-}$mcrA $\Delta$ (mrr-hsdRMS-mcrBC) \$80lacZ $\Delta$ M15 $\Delta$ lacX74 recA1

araD139 $\Delta$ (ara-leu)7697 galU galK rpsL $\left(\mathrm{Str}^{\mathrm{R}}\right)$ endA1 nupG

Wild-type

Tbd_0055::kan

Tbd_0070::kan

Tbd_0094::kan

Tbd_0128-Tbd_0129::kan

Tbd_0137::kan

Tbd_0137-Tbd_0139::kan

Tbd_0146::kan

Tbd_0187::kan

Tbd_0146::kan Tbd_0187::Gen

Tbd_0341::kan

Tbd_0723::kan

Tbd_0820::kan

Tbd_0822::kan

Tbd_1357::kan

Tbd_1398::kan

Tbd_1741::kan

Tbd_1831::kan

Tbd_1948::kan

Tbd_2026-Tbd_2027

Tbd_2060::kan

Tbd_2181::kan

Tbd_2545::kan

Tbd_2628::kan

Tbd_2726::kan

Tbd_1145::kan
Source or reference

Invitrogen

American Type Culture Collection, Manassas,

VA, USA

This work

This work

This work

This work

This work

This work

Beller etal. (2009)

Beller etal. (2009)

This work

This work

Beller etal. (2009)

This work

This work

This work

Beller etal. (2009)

This work

This work

Beller etal. (2009)

This work

This work

This work

This work

This work

Beller etal. (2009)

This work
$\mathrm{pMB1}, \mathrm{Amp}^{\mathrm{R}}$; cloning vector

$\mathrm{pMB1}, \mathrm{Amp}^{\mathrm{R}}, \mathrm{Kan}^{\mathrm{R}}$; harboring the kanamycin resistance selection marker flanked by genomic fragments from the nuoD mutant pMB1, Amp ${ }^{\mathrm{R}}$, pUC19 with Tbd_0187 $(-867,+1396)$ inserted at MCS

pUC19-Tbd0187 with Tn-gent inserted in Tbd_0187

pUC19-Tbd0146 with Tn-kan inserted at +33 of Tbd_0146

pMB1, Amp ${ }^{R}$, pUC19 with Tbd 0137 inserted at MCS

pUC19-Tbd0137 with Tn-kan inserted in Tbd_0137
This work

Beller et al. (2009)

This work

Beller etal. (2009)

This work

This work 
Table 2 | Continued

\begin{tabular}{|c|c|c|}
\hline $\begin{array}{l}\text { Strain, plasmid, or } \\
\text { transposon }\end{array}$ & $\begin{array}{l}\text { Genotype or markers; } \\
\text { characteristics and uses }\end{array}$ & Source or reference \\
\hline \multicolumn{3}{|l|}{ Transposons } \\
\hline $\begin{array}{l}\text { EZ-Tn5 < KAN-2 > Tnp } \\
\text { Transposome Kit }\end{array}$ & $\begin{array}{l}\mathrm{Kan}^{\mathrm{R}} \text {, DNA fragment with kanamycin resistance selection marker } \\
\text { located between Mosaic End Tn5 transposase recognition } \\
\text { sequences }\end{array}$ & Epicentre Biotechnologies \\
\hline Tn-gent & $\begin{array}{l}\text { Gent }^{R} \text {, DNA fragment with gentamicin resistance selection marker } \\
\text { located between Mosaic End Tn5 transposase recognition } \\
\text { sequences }\end{array}$ & Letain et al. (2007) \\
\hline
\end{tabular}

a Indicates that two or three adjacent genes were replaced, not just a single gene.

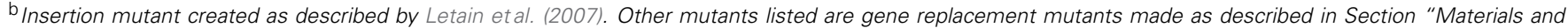
Methods."

\section{RESULTS}

In this study's search for $T$. denitrificans proteins catalyzing nitrate-dependent $\mathrm{Fe}(\mathrm{II})$ oxidation, both targeted and random mutagenesis strategies were undertaken. The choice of gene candidates for targeted mutagenesis was based in part on the results of whole-genome transcriptional studies. Briefly, criteria for targeting genes included the following: (i) $c$-type cytochromes shown to be involved in nitrate-dependent U(IV) oxidation and other membrane-associated $c$-type cytochromes of unknown function, (ii) $c$-type cytochromes upregulated during nitrate-dependent $\mathrm{Fe}$ (II) oxidation and/or highly expressed under relevant conditions, (iii) any genes (not just $c$-type cytochromes) strongly upregulated under nitrate-dependent $\mathrm{Fe}$ (II)-oxidizing conditions.

Accordingly, after presenting data on the physiology of nitratedependent Fe(II) oxidation in T. denitrificans, the Section "Results" covers the following topics: (a) gene expression trends among c-type cytochromes, (b) genes highly upregulated under $\mathrm{Fe}(\mathrm{II}$ )and U(IV)-oxidizing conditions, (c) determination of $\mathrm{Fe}(\mathrm{II})$ oxidizing activity in strains with targeted mutations, and (d) random transposon mutants defective in $\mathrm{Fe}(\mathrm{II})$ oxidation.

\section{ANAEROBIC, NITRATE-DEPENDENT Fe(II) OXIDATION IN T. denitrificans}

Although Straub et al. (1996) reported that T. denitrificans (ATCC 25259, the same strain used in this study) catalyzed autotrophic, nitrate-dependent $\mathrm{Fe}$ (II) oxidation, they did not show any data in support of this finding. In this section, we present some data to reveal important characteristics of this process. Figure 1A displays two aspects of nitrate dependence in Fe(II) oxidation by T. denitrificans: (1) T. denitrificans cells will oxidize Fe(II) in the presence of nitrate but not in its absence and (2) at least initially, there is a strong correlation between $\mathrm{Fe}$ (II) oxidation and nitrate reduction. Regarding the latter point, over the first $2.5 \mathrm{~h}$, a linear regression of $\mathrm{Fe}(\mathrm{II})$ oxidation vs. nitrate consumption had an $r^{2}$ value of 0.999 and a slope of 2.08 for the experiment represented in Figure 1A. The slope of approximately 2 suggests that nitrate was reduced only to nitrite during this period. Subsequently, this ratio increased as nitrate consumption decreased while $\mathrm{Fe}$ (II) oxidation continued, suggesting that nitrite was probably serving as an electron acceptor for further Fe(II) oxidation. Nitrite was not detected in such Fe(II) oxidation studies (at a detection limit of $150 \mu \mathrm{M}$, accounting for dilution), which may not be surprising because the total amount of nitrate reduced in such experiments was in the detection limit range (160 $\mu \mathrm{M}$ for the experiment represented in Figure 1A).

In light of extensive discussions in the literature about the potential role that nitrite and other denitrification intermediates could play in abiotic oxidation during nitrate-dependent Fe(II) oxidation (Carlson et al., 2012; Picardal, 2012; Kopf et al., 2013), we carried out abiotic studies of anaerobic Fe(II) oxidation in the presence of $150 \mu \mathrm{M}$ nitrite (approximately the maximum amount of nitrite that could be produced in our studies, based on total nitrate consumption) and in the absence of nitrate. Such studies (Figure 1C) revealed negligible $\mathrm{Fe}(\mathrm{II})$ oxidation caused by nitrite under our assay conditions. $120 \mu \mathrm{M}$ of Fe(II) was oxidized in both the presence and absence of $150 \mu \mathrm{M}$ nitrite (Figure 1C). Thus, abiotic oxidation by nitrite probably accounts for a small portion of the $\sim 500 \mu \mathrm{M} \mathrm{Fe}$ (II) typically oxidized in our experiments (e.g., for the experiments represented in Figures 1A,B).

One noteworthy difference between nitrate-dependent Fe(II) and $\mathrm{U}(\mathrm{IV})$ oxidation by $T$. denitrificans is that $\mathrm{U}(\mathrm{IV})$ oxidation appears to require $\mathrm{H}_{2}$ to proceed (Beller, 2005), whereas $\mathrm{Fe}$ (II) oxidation does not (Figure 1B). In the experiment represented in Figure $1 \mathbf{B}$, only $\mathrm{N}_{2}$ was present in the headspace, whereas in the experiment represented in Figure 1A, the headspace consisted of a mixture of $\mathrm{N}_{2} / \mathrm{CO}_{2} / \mathrm{H}_{2}$ (see Materials and Methods). The same amount of $\mathrm{Fe}(\mathrm{II})$ was oxidized either with or without $\mathrm{H}_{2}$ in the headspace $(\sim 500 \mu \mathrm{M})$.

These studies show that Fe(II) can be the sole electron donor for T. denitrificans during nitrate-dependent $\mathrm{Fe}$ (II) oxidation, in contrast to the organotrophic $\mathrm{Fe}(\mathrm{II})$ oxidizers that require an electron donor, such as acetate, in addition to Fe(II). However, we did not find evidence that nitrate-dependent Fe(II) oxidation could support growth of T. denitrificans in liquid medium over a 20-day period.

\section{GENE EXPRESSION TRENDS AMONG $\boldsymbol{c}$-TYPE CYTOCHROMES}

For reasons discussed previously [e.g., the relatively high reduction potential of some $c$-type cytochromes; a number of $c$-type 
Table 3 | PCR primers used in this study.

\begin{tabular}{|c|c|}
\hline Primer & Sequence $^{\mathrm{a}}\left(5^{\prime}-3^{\prime}\right)$ \\
\hline Tbd_0055-1 & ATTCGAGGGCGAAGCCGAAG \\
\hline Tbd_0055-2 & GCAGAATTCAAGGGGTGAAGGCGCGTCTC \\
\hline KO3-EcoRI & GCAGAATTCCAACCATCATCGATGAATTG-3' \\
\hline $\mathrm{KO} 4$ & CAACCCTGAAGCTTGCATGC \\
\hline Tbd_0055-5 & GCATCTAGATTAGATCGCCGCCTTCAACTCGC \\
\hline Tbd_0055-6 & CCTCGACCGACATCTCGATC \\
\hline Tbd_0070-1 & AAGGTCGGCATCCGCTTCAC \\
\hline Tbd_0070-2 & GCAGAATTCTCAGCGGGAAAAGTGCTGCATCA \\
\hline Tbd_0070-5 & GCATCTAGACGATCATCGACAAGCGCACG \\
\hline Tbd_0070-6 & GCTCTGCGTCGTATCGAAGG \\
\hline Tbd_0094-1 & TGCGACCGCTACGAAGTGCA \\
\hline Tbd_0094-2 & GCAGAATTCTGCTTCTCCTCGGAATTGAC \\
\hline Tbd_0094-5 & GCATCTAGACCGCATGACGAGCATGCTGA \\
\hline Tbd_0094-6 & GATGGCCGAGCCGAGGATGT \\
\hline Tbd_0128-Tbd_0129-1 & TTTCTTGAACAGGGATTGCA \\
\hline Tbd_0128-Tbd_0129-2 & GCAGAATTCAGGGTGCTCCAAAAAGTCGA \\
\hline Tbd_0128-Tbd_0129-5 & GCATCTAGAACCTTCCACGACGAGAATTG \\
\hline Tbd_0128-Tbd_0129-6 & TTCAACGAGGACAATTTCGG \\
\hline Tbd_0137-f $\mathrm{f}^{\mathrm{b}}$ & GGTACCAAGGATGCGTCCCTAGAGTGAAG \\
\hline Tbd_0137-r ${ }^{b}$ & GGTACCTGCAATTCCTCGACGAAATGG \\
\hline Tbd_0137-Tbd_0139-1 & CACGCTTCGACAATATGGAC \\
\hline Tbd_0137-Tbd_0139-2 & GCAGAATTCTTACACTCTAGGGACGCATCC \\
\hline Tbd_0137-Tbd_0139-5 & GCATCTAGAGCGGGGTATTCGAGGAAGAC \\
\hline Tbd_0137-Tbd_0139-6 & TAGACGAATAGCGCCGACAG \\
\hline Tbd_0341-1 & GTCCCTCCGACCTTCAGCAG \\
\hline Tbd_0341-2 & GCAGAATTCGTGCACCGAACCTGACCGAC \\
\hline Tbd_0341-5 & GCATCTAGATTAGCTCATTGCTTGTCCTTCGG \\
\hline Tbd_0341-6 & GACGATCGAGAAGGTCGACG \\
\hline Tbd_0820-1 & AAGCTCGCGGTCAGGTCTTG \\
\hline Tbd_0820-2 & GCAGAATTCAAGACCCTCGAACGGGTTGA \\
\hline Tbd_0820-5 & GCATCTAGATGATTTTCGCGCCAGCTGGG \\
\hline Tbd_0820-6 & GGGTCTTTGAGCGTCTGTTC \\
\hline Tbd_0822-1 & TTCTTCAACCTCGTGCTCGG \\
\hline Tbd_0822-2 & GCAGAATTCTTAATTGTTCTCGTGCCAGACGT \\
\hline Tbd_0822-5 & GCATCTAGAGCCGAACAGACGCTCAAAGA \\
\hline Tbd_0822-6 & AGCATGCTGCCCTGGATCA \\
\hline Tbd_1357-1 & TGTTCCAGGCGCCTTACTTG \\
\hline Tbd_1357-2 & GCAGAATTCTCCCTGTTTCTGGCTTACGC \\
\hline Tbd_1357-5 & GCATCTAGAGAGAGCTTCCGCAAGCCTTT \\
\hline Tbd_1357-6 & TCTGCTCGACCTGTGTTTGC \\
\hline Tbd_1741-1 & TTCATCCСCCTGTACCTCGC \\
\hline Tbd_1741-2 & GCAGAATTCTTACTTAGGCCTGGGCACGACGC \\
\hline Tbd_1741-5 & GCATCTAGATCAACCTCAACGACCTCGGT \\
\hline Tbd_1741-6 & TGCGCTGCTCGAGCGACTGT \\
\hline
\end{tabular}

(Continued)
Table 3 | Continued

\begin{tabular}{|c|c|}
\hline Primer & Sequence $^{a}\left(5^{\prime}-3^{\prime}\right)$ \\
\hline Tbd_1831-1 & CCAGATGTCGTTCTGGGGTG \\
\hline Tbd_1831-2 & GCAGAATTCTTAGCCAGTCACCCTTTCCG \\
\hline Tbd_1831-5 & GCATCTAGATGCGATCGTCGGTGATCTCG \\
\hline Tbd_1831-6 & GGCAGTTCGATGCCGTAGTG \\
\hline Tbd_2026-Tbd_2027-1 & CCATCGCGACGATCATGTAG \\
\hline Tbd_2026-Tbd_2027-2 & GCAGAATTCCTTGCTCGCTCTCTCCTCGG \\
\hline Tbd_2026-Tbd_2027-5 & GCATCTAGAAATACTGAGCCGAGCCCTCT \\
\hline Tbd_2026-Tbd_2027-6 & CGACTTCATTGAGGCGAGCT \\
\hline Tbd_2060-1 & CTATCACGTGCAGACCGGTG \\
\hline Tbd_2060-2 & GCAGAATTCTCA GCACAGCACGACGTTGAG \\
\hline Tbd_2060-5 & GCATCTAGAGGTGGTTCGGCGACTACAAC \\
\hline Tbd_2060-6 & CGATGCGCACGAGATCGAAC \\
\hline Tbd_2181-1 & TTGCGCAGGAACATCGCGAG \\
\hline Tbd_2181-2 & GCAGAATTCGAGTTCTCCAAGCATCAAAG \\
\hline Tbd_2181-5 & GCATCTAGACCCACCCCTGATCGAGGAGA \\
\hline Tbd_2181-6 & TCTCGAAGGGGACTCGATCC \\
\hline Tbd_2545-1 & TACTCCTTGTCCAGCAGGTG \\
\hline Tbd_2545-2 & GCAGAATTCGATCTTCCCATCCATCCGAT \\
\hline Tbd_2545-5 & GCATCTAGATCTGCAACATCAGCATGCTC \\
\hline Tbd_2545-6 & TCGCGATCGCCTACATCGAC \\
\hline Tbd_2628-1 & AGCAGCGTCGGGCCTTTCTG \\
\hline \multirow[t]{2}{*}{ Tbd_2628-2c } & CAATTCATCGATGATGGTTGCTACATCGTG \\
\hline & TTTTCCCCTTTGC \\
\hline $\mathrm{KO}^{\mathrm{C}}$ & CAACCATCATCGATGAATTG \\
\hline \multirow[t]{2}{*}{ Tbd_2628-5c } & GCATGCAAGCTTCAGGGTTGTAGGCGA \\
\hline & GCGGAGATGCGAG \\
\hline Tbd_2628-6 & TCGGTCAGCCGCGCTTTGCG \\
\hline
\end{tabular}

a Relevant restriction sites are underlined.

b ForTbd_0137, an insertion mutant was made according to the method described previously (Letain etal., 2007).

${ }^{C}$ Restriction sites were not included in primers for the Tbd_2628 mutant because the recombinant PCR product used to replace Tbd_2628 was generated by annealing the homologous ends of the individual PCR products.

cytochromes identified as having a role in anaerobic U(IV) and $\mathrm{Fe}(\mathrm{II})$ oxidation], $c$-type cytochromes are primary candidates for catalyzing nitrate-dependent $\mathrm{Fe}(\mathrm{II})$ oxidation in T. denitrificans. The genome of T. denitrificans encodes more than 50 predicted proteins with the CXXCH heme-binding motif, many of which are mono and diheme $c$-type cytochromes (Beller et al., 2006a). However, BLASTP searches (Altschul et al., 1997) reveal that the genome does not encode homologs of $c$-type cytochromes that have been associated with $\mathrm{Fe}(\mathrm{II})$ oxidation in other bacteria, such as pioA (Jiao and Newman, 2007) or foxE (Croal et al., 2007; Saraiva et al., 2012) in anoxygenic phototrophic bacteria, $m$ toA in Sideroxydans lithotrophicus ES-1 (Liu et al., 2012), or cyc2 in Acidithiobacillus ferrooxidans (Castelle et al., 2008). The genome also does not encode proteins associated with these $c$-type cytochromes, such as PioB, PioC, FoxY, FoxZ, MtoB, or CymA $\mathrm{ES}_{-1}$. 


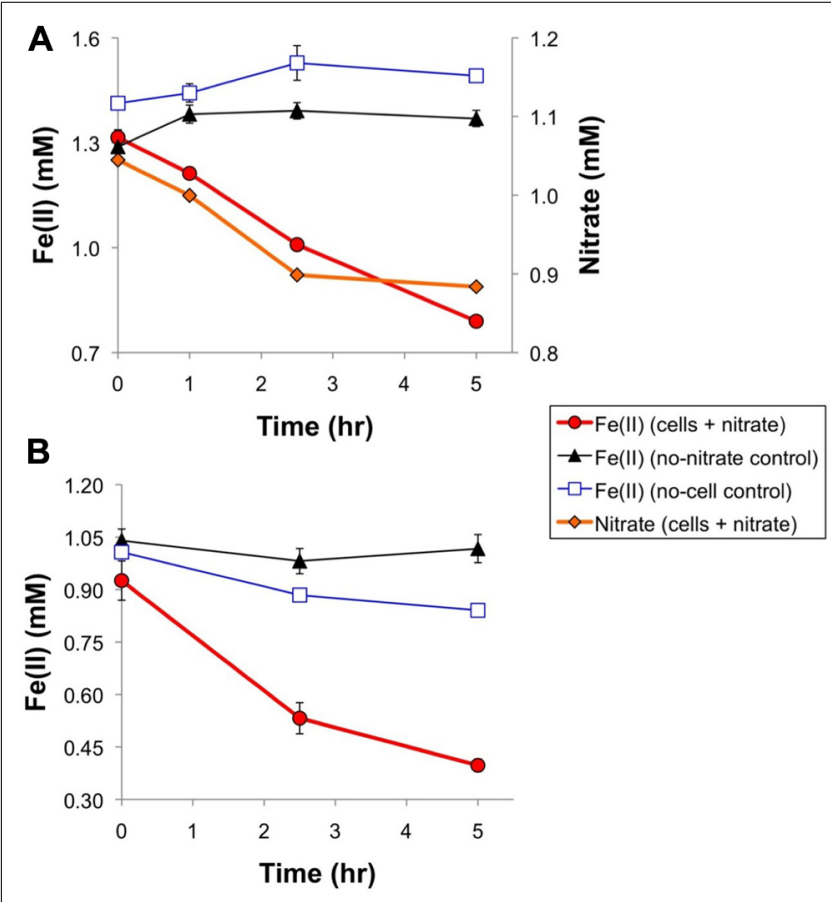

C

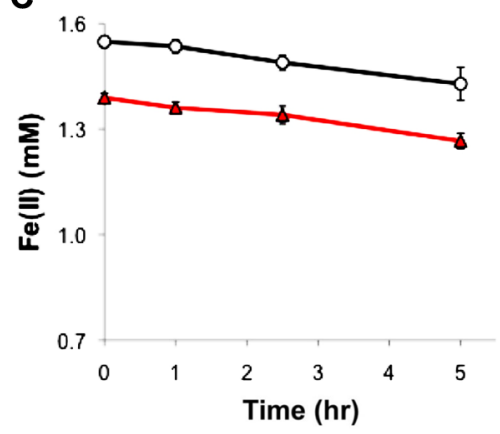

$\triangle-$ With nitrite (150 uM) $-\infty$ Without nitrite

FIGURE 1 | Anaerobic cell suspension studies of nitrate-dependent Fe(II) oxidation by wild-type $\boldsymbol{T}$. denitrificans and related abiotic studies. (A) Cell suspensions with the headspace consisting of the standard glove box atmosphere (nominally $85 \% \mathrm{~N}_{2}-10 \% \mathrm{CO}_{2}-5 \% \mathrm{H}_{2}$ ), (B) cell suspensions with ultra high-purity $\mathrm{N}_{2}$ in the headspace, and (C) abiotic studies (without T. denitrificans cells) under the same conditions as in (A) but with $150 \mu \mathrm{M}$ nitrite (the typical amount of nitrate consumed in cell suspension experiments) replacing $1 \mathrm{mM}$ nitrate. The $\mathrm{OD}_{600}$ of the experiments represented by (A) and (B) was 1.8. Data points represent the averages of triplicates and error bars represent one standard deviation.

Expression data for genes encoding predicted proteins with the CXXCH motif (including $c$-type cytochromes) are presented in Figure 2. The $\log _{2}$ intensity data plotted in Figure 2 were normalized as described in Section "Materials and Methods" and represent, with one exception, the average of three biological replicates, each of which had three technical on-chip replicates. The exception is the " $\mathrm{UO}_{2}$ (synth.)" column, which represents only one biological replicate. The exposure conditions for the arrays (displayed directly above the heat map) listed from left to right are the same as the conditions listed in Table $\mathbf{1}$ from top to bottom.
Some of the most highly expressed $c$-type cytochromes under a range of conditions [including thiosulfate and $\mathrm{Fe}$ (II) oxidation under denitrifying conditions] have known functions associated with denitrification or S-compound oxidation, including nirS (Tbd_0077), norC (Tbd_0562), soxA (Tbd_0564), soxX (Tbd_0567), and dsrJ (Tbd_2476). Further, Tbd_1831 is a cytochrome $c_{1}$ subunit of complex III (cytochrome $b c_{1}$-type ubiquinol oxidoreductase). However, other highly expressed, putative $c$-type cytochromes have unknown functions, including Tbd_0137 (which is clustered in the genome with other $c$ - and b-type cytochromes), Tbd_1398, and Tbd_2726. Note that narH (Tbd_1404; $ß$ subunit of the respiratory nitrate reductase) was highly expressed but is not a $c$-type cytochrome - it is an Fe-S protein. Open reading frames (ORFs) shown in blue in Figure 2 were chosen as targets for insertion or replacement mutations. Among the more highly expressed genes that were not chosen as targets were nirS, norC, and narH (because these were thought to be essential genes under denitrifying conditions) and $\operatorname{sox} A$, soxX, and $d s r J$ (whose S-compound oxidation functions are well known). More detailed discussion of target selection is presented later.

Additional information footnoted in Figure 2 merits mention here. Two diheme $c$-type cytochromes included in the figure, Tbd_0146 and Tbd_0187, were experimentally shown to play a role in nitrate-dependent $\mathrm{U}(\mathrm{IV})$ oxidation in T. denitrificans using insertion mutations and complementation in trans (Beller et al., 2009). These two proteins, along with Tbd_0723 and Tbd_1398, were experimentally shown to be membrane associated (Beller et al., 2009). Sucrose-density-gradient ultracentrifugation experiments were intended to identify OM proteins [which might be expected to directly contact insoluble U(IV) or Fe(II) phases], but the density separation was clearly not specific to only OM proteins and one can only claim that Tbd_0146, Tbd_0187, Tbd_0723, and Tbd_1398 are membrane-associated, not necessarily OM proteins (Beller etal., 2009). As membrane-associated $c$-type cytochromes of unknown function, all four of these proteins were clearly of interest as candidates for catalyzing anaerobic Fe(II) oxidation.

Upregulation of genes encoding predicted proteins with the $\mathrm{CXXCH}$ motif is represented in Figure 3. In this Venn diagram, genes are listed that are at least twofold upregulated relative to control conditions (thiosulfate and $\mathrm{H}_{2}$; Group VII) at $P \leq 0.0001$. All exposure conditions shown include $\mathrm{H}_{2}$, and consist of Group V $\left(\mathrm{FeCO}_{3}\right.$ and $\left.\mathrm{H}_{2}\right)$, Group VI $\left(\mathrm{UO}_{2}\right.$ and $\left.\mathrm{H}_{2}\right)$, and Group II $\left[\mathrm{Fe}^{2+}(\mathrm{aq})\right.$ and $\left.\mathrm{H}_{2}\right]$; recall that, in T. denitrificans, $\mathrm{H}_{2}$ is required for nitrate-dependent $\mathrm{U}(\mathrm{IV})$ oxidation (Beller, 2005). Looking across the entire genome, 476 genes were upregulated at least twofold under these conditions, and for putative $c$-type cytochromes, 15 genes met this twofold criterion. The locus tags for these upregulated genes are identified in Figure 3. The largest number of upregulated genes was for nitrate-dependent, $\mathrm{Fe}^{2+}$-oxidizing conditions (12 genes total, with 10 genes unique to this exposure condition). The single gene that was upregulated at least twofold under all three conditions shown was Tbd_0723, which is putatively a $\mathrm{Fe}^{2+}$ permease that is located in a large gene cluster associated with iron acquisition (Beller et al., 2006b). No putative $c$-type cytochrome genes were 


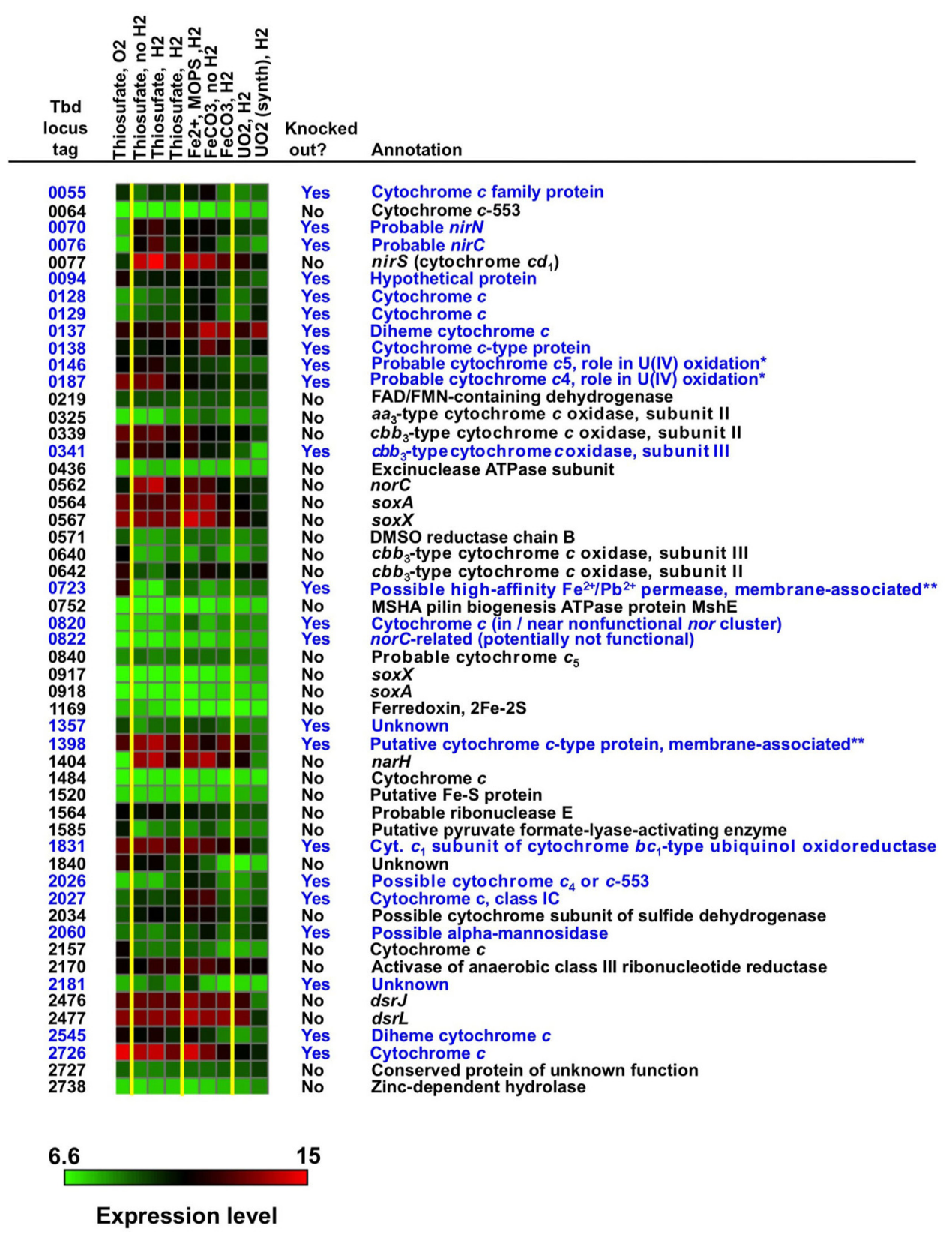

FIGURE 2 | Expression profiles and annotations of genes encoding proteins with the $\mathrm{CXXCH}$ heme-binding motif, many of which are $c$-type cytochromes (see text). The $\log _{2}$ intensity data plotted in this figure were normalized as described and represent, with one exception, the average of three biological replicates and three technical replicates (see text). The exposure conditions for the arrays (displayed directly above the heat map) listed from left to right are the same as the conditions listed in Table $\mathbf{1}$ from top to bottom. Genes highlighted in blue were targeted for mutation studies.
An intensity color scale is shown. To provide some perspective for the intensity scale, the following are the average percentile values for intensity for all genes on all arrays: 50 th percentile $=8.0,75$ th percentile $=9.0,90$ th percentile $=10.4$, 95th percentile $=11.3$, and 100th percentile $=15.1$. The symbol "*" represents genes previously shown to be associated with nitrate-dependent U(IV) oxidation (Beller et al., 2009) and "**" represents genes encoding proteins that were experimentally shown to be membrane associated (see text). uniquely upregulated under nitrate-dependent, $\mathrm{UO}_{2}$-oxidizing conditions (Figure 3). Most of the upregulated putative $c$-type cytochrome genes were targeted for insertion mutations (see blue highlighted ORFs in Figure 2). Those that were not targeted included Tbd_0567 (soxX, discussed earlier), Tbd_2170 (which is not a cytochrome, but rather an Fe-S protein that is an activase for anaerobic ribonucleoside triphosphate reductase, a glycyl radical enzyme), Tbd_0325 (subunit II of $a a_{3}$-type cytochrome $c$ oxidase), and Tbd_0642 (subunit II of $c b b_{3}$-type cytochrome $c$ oxidase, $\mathrm{CcoO}$ ). Also shown in Figure 3 are putative $c$-type cytochrome genes that were highly expressed (>90th percentile expression) under all anaerobic conditions tested (including the 


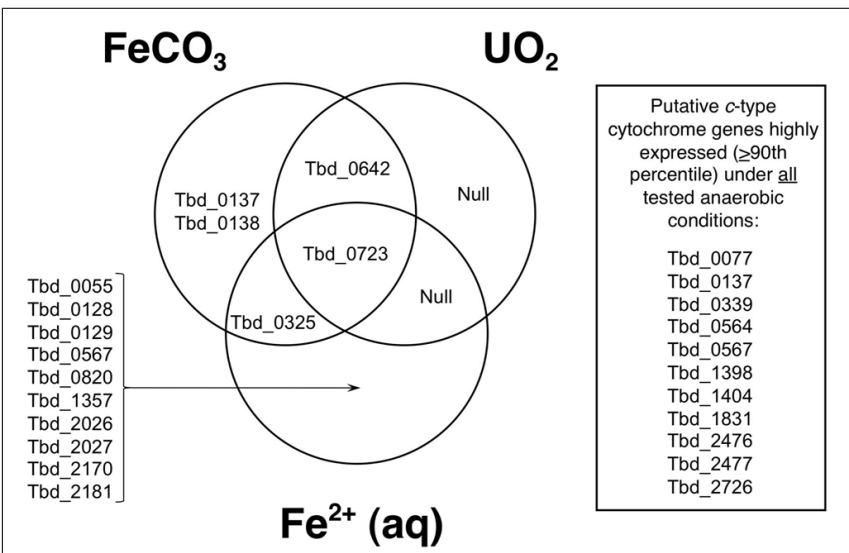

FIGURE 3 | Venn diagram showing genes from Figure 2 (mostly $c$-type cytochromes) that are at least twofold upregulated relative to control conditions (thiosulfate and $\mathbf{H}_{\mathbf{2}}$; Group VII) at $\boldsymbol{P} \leq \mathbf{0 . 0 0 0 1}$. All exposure conditions shown include $\mathrm{H}_{2}$, and consist of Group $\mathrm{V}\left(\mathrm{FeCO}_{3}\right.$ and $\left.\mathrm{H}_{2}\right)$, Group VI $\left(\mathrm{UO}_{2}\right.$ and $\left.\mathrm{H}_{2}\right)$, and Group II [ $\mathrm{Fe}^{2+}(\mathrm{aq})$ and $\mathrm{H}_{2}$ ]. Also shown are genes from Figure $\mathbf{2}$ that are highly expressed under all anaerobic conditions tested (see text).

control, thiosulfate-oxidizing conditions). Most of these genes have already been addressed except Tbd_0339, which is a homolog of Tbd_0642 (these two share 51\% amino acid sequence identity).

\section{A COMMON GROUP OF UPREGULATED GENES UNDER Fe(II)- AND U(IV)-OXIDIZING CONDITIONS}

The search for enzyme candidates for nitrate-dependent Fe(II) oxidation extended beyond $c$-type cytochromes to any genes that were highly upregulated under conditions of interest. Data analysis revealed that a common group of genes was upregulated under nitrate-dependent $\mathrm{FeCO}_{3}-, \mathrm{Fe}^{2+}$-, and $\mathrm{UO}_{2}$-oxidizing conditions
(Groups V, II, and VI, respectively; Table 1) relative to nitratedependent thiosulfate-oxidizing conditions (Group VII). Of the top 25 upregulated genes under each of the three conditions of interest (i.e., $\mathrm{FeCO}_{3}$-, $\mathrm{Fe}^{2+}$-, and $\mathrm{UO}_{2}$-oxidizing), a group of 16 genes belonged to all three top- 25 groups. These 16 genes are shown in red in Figure 4, a volcano plot, which graphs $\log _{10}$ odds of differential expression vs. $\log _{2}$ fold differential expression for all 2,832 ORFs identified in the draft genome at the time of microarray design (the finished genome is annotated to have 2,827 ORFs; Beller et al., 2006a). Upregulation under $\mathrm{FeCO}_{3-}, \mathrm{Fe}^{2+}$, and $\mathrm{UO}_{2}$-oxidizing conditions is plotted in the gray regions of Figures $4 \mathrm{~A}-\mathrm{C}$, and the ORFs most highly upregulated relative to thiosulfate-oxidizing conditions are plotted furthest to the right. The group of 16 genes clearly contains many of the most highly upregulated genes under all three conditions, ranging from 5- to 39-fold upregulation and averaging 13 -fold upregulation relative to thiosulfate-oxidizing conditions.

The identities (locus tag numbers and annotation) of the 16 highly upregulated genes under $\mathrm{Fe}(\mathrm{II})$ - and $\mathrm{U}(\mathrm{IV})$-oxidizing conditions are shown in Figure 5, along with the $\log _{2}$ intensity data for expression of these genes under relevant conditions. The 16 genes are listed in decreasing order of geometric-average, fold upregulation for nitrate-dependent $\mathrm{FeCO}_{3}-, \mathrm{Fe}^{2+}$-, and $\mathrm{UO}_{2}$-oxidizing conditions relative to nitratedependent thiosulfate-oxidizing conditions [ranging from 22 -fold upregulation (Tbd_2628) to 6.6-fold upregulation (Tbd_1513)]. In some cases, absolute expression levels are very high in addition to relative expression levels. This is particularly true for Tbd_2628, which had $\log _{2}$ intensities of 13.1 to 13.3 under the non-control conditions shown (well above the 95th percentile value of 11.3 for all genes on all arrays). Note that the top-ranked two genes are indicated in Figure 4 with blue arrows (Tbd_2628) and green arrows (Tbd_1948). Both of these genes were targeted for insertion/replacement mutations.
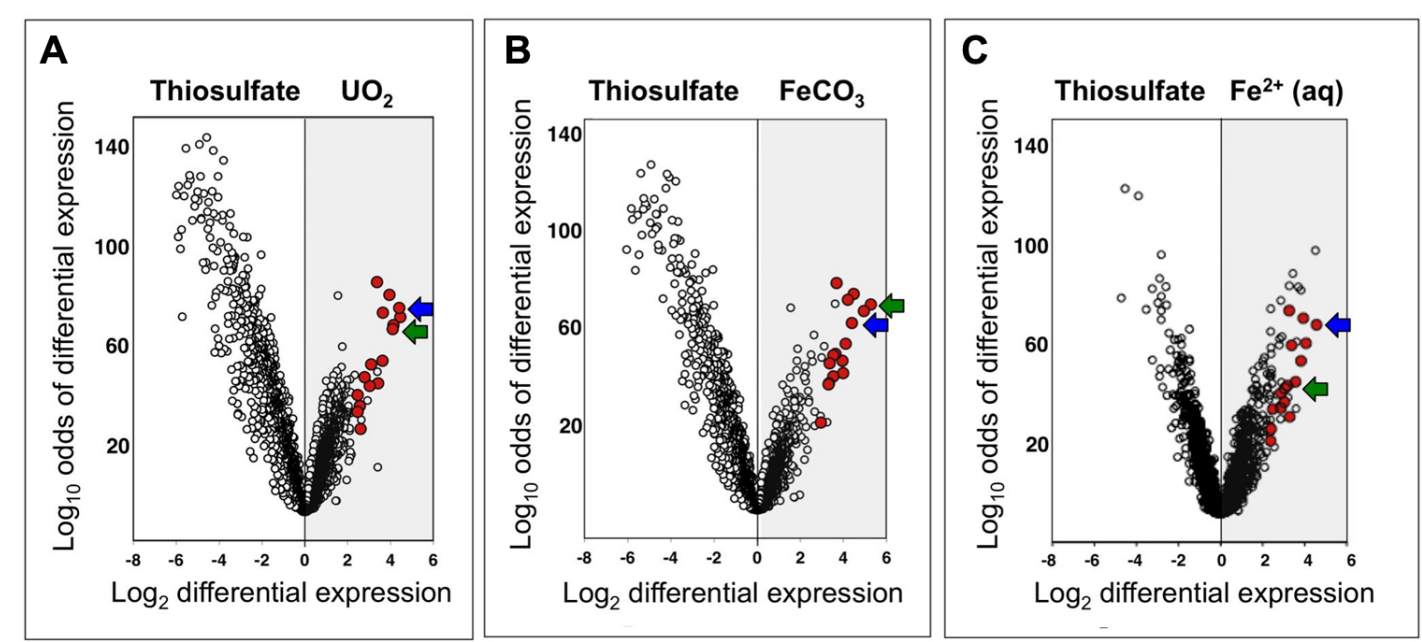

FIGURE 4 | Volcano plots of $\log _{10}$ odds of differential expression versus $\log _{2}$ fold differential expression for all $T$. denitrificans genes under nitrate-dependent $\mathrm{UO}_{2}$-oxidizing (A), $\mathrm{FeCO}_{3}$-oxidizing (B), and $\mathrm{Fe}^{2+}$-oxidizing (C) conditions (Groups VI, V, and II, respectively; Table 1) relative to nitrate-dependent thiosulfate-oxidizing conditions (Group VII). A highly upregulated group of 16 genes is highlighted in red (see text). Two of the most highly upregulated genes are indicated with blue arrows (Tbd_2628) and green arrows (Tbd_1948). 

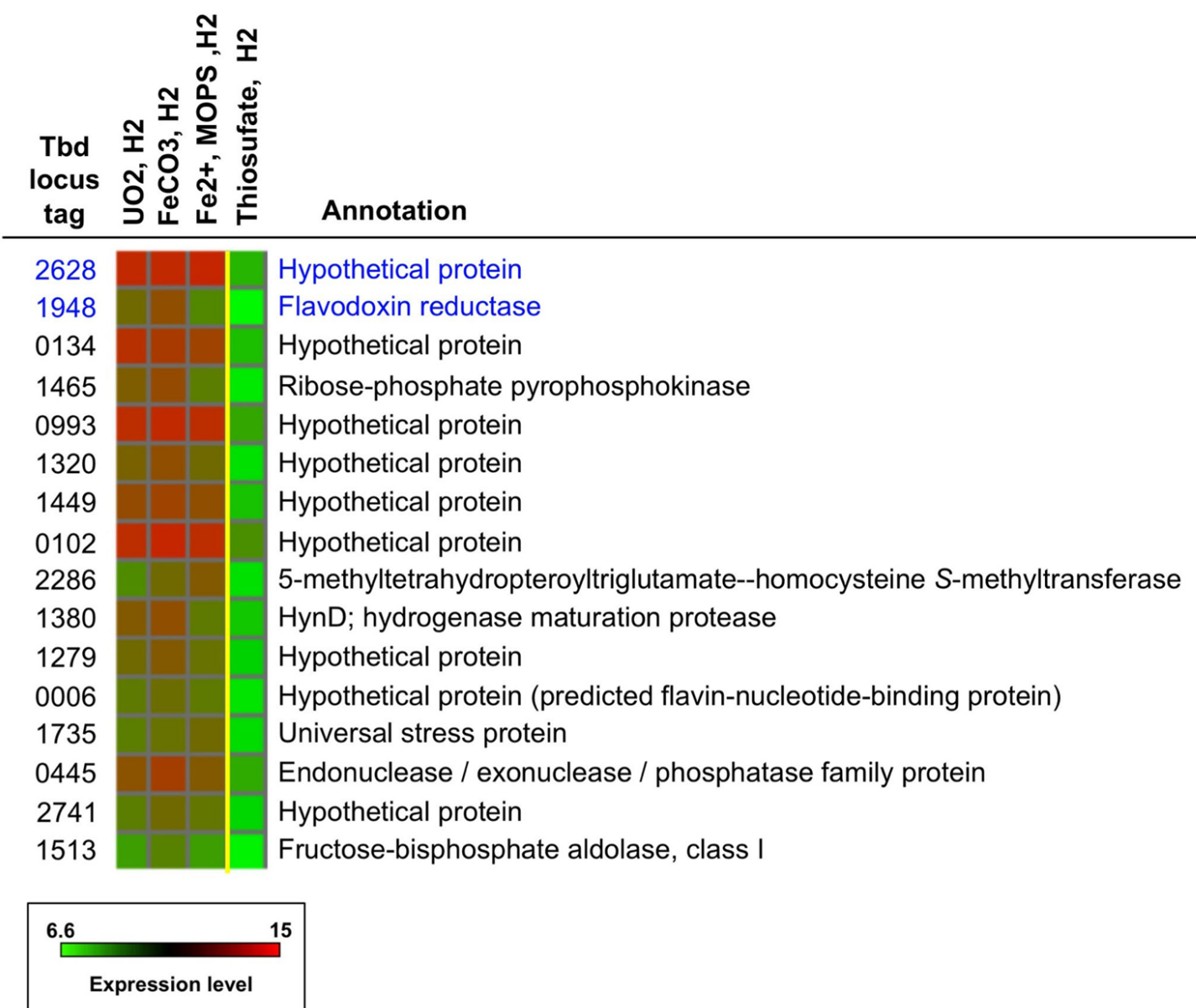

FIGURE 5 | Expression profiles and annotations for a group of 16 of the most highly expressed genes under under nitrate-dependent $\mathrm{UO}_{2}-\mathrm{FeCO}_{\mathbf{3}}^{-}$, and $\mathbf{F e}^{2+}$-oxidizing conditions (Groups VI, V, and II, respectively; see text). The two genes highlighted in blue were targeted for mutation studies. The intensity color scale is the same as for Figure $\mathbf{2}$

As shown in Figure 5, many (nine) of the 16 genes shown encode proteins of unknown function (hypothetical proteins), including Tbd_2628. Tbd_1948 is annotated as a flavodoxin reductase and thus may have a function related to electron transfer. Other encoded proteins on the list may also have some role in electron transfer, including Tbd_0006 (a predicted flavin-nucleotide-binding protein) and Tbd_0993 (located upstream of a ubiquinone biosynthesis gene, Tbd_0994). As might be expected, some of these genes may be associated with stress response (Tbd_1735) and metal efflux (e.g., Tbd_1320 is located near a gene cluster associated with copper resistance, Tbd_1324-1326; Beller etal., 2006a; and Tbd_2741 is located next to a gene annotated as a heavy metal-translocating P-type ATPase, Tbd_2740). A noteworthy gene listed in Figure $\mathbf{5}$ is Tbd_1380, hynD, a hydrogenase maturation protease that is the first gene transcribed in an operon that encodes a periplasmic group 1 [NiFe]hydrogenase (Beller et al., 2006a). This is of particular interest because, as noted previously, $T$. denitrificans only carries out nitrate-dependent U(IV) oxidation when $\mathrm{H}_{2}$ oxidation is occurring (Beller, 2005). However, the gene encoding the large (active-site-bearing) subunit of the associated hydrogenase (Tbd_1375, hynL) was previously knocked out (Letain et al., 2007) and the resulting mutant strain was not defective in nitrate-dependent $\mathrm{U}(\mathrm{IV})$ oxidation (H. R. Beller, unpublished data).

\section{EFFECTS OF TARGETED MUTATIONS ON Fe(II) OXIDATION}

In total, 26 insertion or replacement mutants were tested in assays for anaerobic, nitrate-dependent Fe(II) oxidation (Table 4). The specific Fe(II) oxidation activities of these mutant strains are listed in Table 4 along with the activity of the wild-type (for comparison) and the rationale for targeting the genes listed. The specific activities are based on averages of at least three biological replicates; all experiments included both no-nitrate and no-cell controls. In some cases, multiple experiments were performed to confirm results. Of strains with targeted mutations, none was more than $15 \%$ defective relative to the wild-type. Of particular note is the observation that the two $c$-type cytochrome mutants that were found to be $\sim 50 \%$ defective in nitrate-dependent U(IV) oxidation, $\Delta$ Tbd_0146 and $\Delta$ Tbd_0187 (Beller et al., 2009), were not 
Table 4 | Specific rates of nitrate-dependent Fe(II) oxidation by T. denitrificans wild-type and mutants under study.

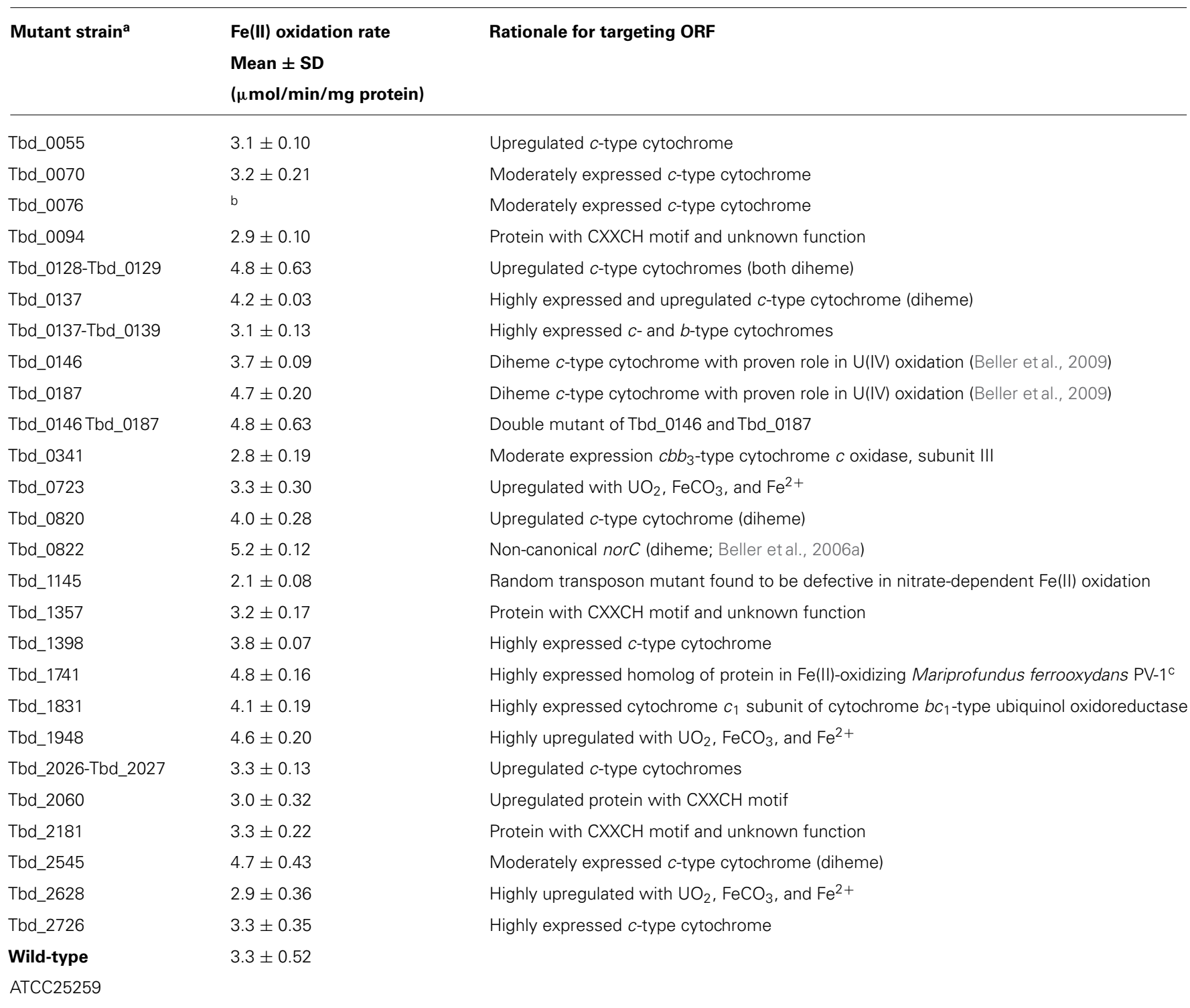

a Insertion or replacement mutation was made for gene(s) with indicated locus tag(s).

b Slow growth precluded performing an assay with this strain (this gene, located in the nir operon, may be essential for denitrification).

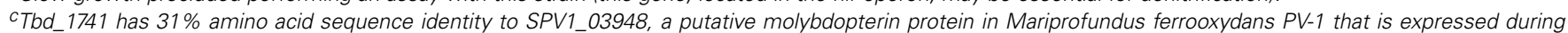

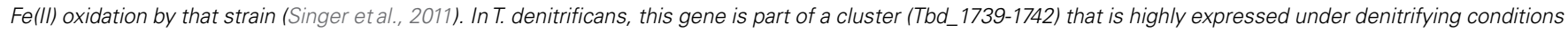
(data not shown).

at all defective in nitrate-dependent $\mathrm{Fe}(\mathrm{II})$ oxidation, nor was the double-mutant strain (Table 4).

\section{RANDOM TRANSPOSON MUTANTS DEFECTIVE IN Fe(II) OXIDATION}

More than 20,000 random transposon mutants were screened for nitrate-dependent $\mathrm{Fe}$ (II) oxidation. The most reproducibly defective strain had a mutation in nuoD (Tbd_1145), which encodes the $\mathrm{D}$ subunit of NADH:ubiquinone oxidoreductase (complex I). Fe(II) oxidation assays revealed that this mutant was $\sim 35 \%$ defective in $\mathrm{Fe}$ (II) oxidation relative to the wild-type (Table 4). Notably, it was $\sim 33 \%$ defective in nitrate reduction in an independent positive control assay in which thiosulfate was the electron donor rather than $\mathrm{Fe}(\mathrm{II})$. These results are consistent with both (a) the expected role of complex I in transferring electrons to the ubiquinone pool, and ultimately, to nitrate reductase via ubiquinol and (b) the tight coupling between Fe(II) oxidation and nitrate reduction. In effect, the mutation in nuoD is likely causing a direct defect in delivery of reducing equivalents to nitrate reductase and is thus indirectly causing a defect in nitrate-dependent Fe(II) oxidation.

\section{DISCUSSION}

Although we were able to demonstrate that there is a strong linkage between $\mathrm{Fe}(\mathrm{II})$ as the sole electron donor and nitrate reduction 
to nitrite, and that abiotic interactions of nitrite with $\mathrm{Fe}$ (II) contribute little, if anything, to this process, we have no evidence that this linkage results in energy conservation or growth. It is clear that nitrate-dependent Fe(II) oxidation in T. denitrificans, unlike nitrate-dependent $\mathrm{U}(\mathrm{IV})$ oxidation, has no co-metabolic dependence on $\mathrm{H}_{2}$ oxidation and is not catalyzed by the diheme $c$-type cytochromes Tbd_0146 and Tbd_0187. In fact, none of the $c$-type cytochrome genes targeted in this study was shown to be important to nitrate-dependent $\mathrm{Fe}$ (II) oxidation. Possible explanations include the following: (a) one or more $c$-type cytochromes are involved in nitrate-dependent $\mathrm{Fe}(\mathrm{II})$ oxidation in T. denitrificans, but we did not target the appropriate genes in this study, (b) since the T. denitrificans genome encodes many $c$-type cytochromes, one or more $c$-type cytochromes are being upregulated in mutant strains to compensate for the loss of the targeted $c$-type cytochrome, or (c) c-type cytochromes are not involved in nitrate-dependent $\mathrm{Fe}$ (II) oxidation in T. denitrificans.

The only significantly defective mutant identified in this study had a mutation in nuoD (Tbd_1145) of NADH-ubiquinone oxidoreductase (complex I in the electron transport chain); this strain was equally defective in nitrate-dependent Fe(II) oxidation and nitrate-dependent thiosulfate oxidation (tested independently). In a sense, this can be easily rationalized in that complex I mediates transfer of electrons derived from $\mathrm{NADH}+\mathrm{H}^{+}$oxidation to the quinone pool (ubiquinone), which can then pass these electrons to the $b$-cytochrome (NarI) subunit of nitrate reductase (NarGHI; Berks et al., 1995; Zumft, 1997; Richardson, 2000). A mutation in complex I would presumably preclude this electron transfer to nitrate reductase and create the observed defective phenotypes. However, the source of $\mathrm{NADH}$ is problematic in light of the electron donor involved, namely, Fe(II). The reduction potential of the $\mathrm{Fe}$ (III)-NTA/Fe(II)-NTA couple, which is probably most relevant to our $\mathrm{Fe}(\mathrm{II})$ oxidation assay, is very high: $+0.372 \mathrm{~V}$ ( $\mathrm{pH} \mathrm{7}$; Ilbert and Bonnefoy, 2013). This reduction potential is still exergonic in combination with nitrate reduction to nitrite (the $\mathrm{NO}_{3}^{-} / \mathrm{NO}_{2}^{-}$reduction potential is $0.42 \mathrm{~V}$ at $\mathrm{pH} 7$; Ilbert and Bonnefoy, 2013) but is far too high to result in direct NADH production during nitrate-dependent $\mathrm{Fe}(\mathrm{II})$ oxidation. Thus, it seems that reverse electron transfer would be required to produce $\mathrm{NADH}$ to feed into complex I and ultimately reduce nitrate. A reverse electron transfer pathway proposed for the aerobic, acidophilic Fe(II)-oxidizing bacterium, Acidithiobacillus ferrooxidans, involves transfer of some portion of $\mathrm{Fe}(\mathrm{II})$-derived electrons "uphill" (i.e., in a thermodynamically unfavorable direction) through complex III, ubiquinone, and complex I to produce $\mathrm{NADH}$ (Bird et al., 2011 and references therein). If this reverse electron transfer mechanism via complex III (cytochrome $b c_{1}$ complex) is accurate and relevant to T. denitrificans, it is difficult to explain our finding that a mutant in the $c_{1}$-cytochrome subunit of the cytochrome $b c_{1}$ complex (Tbd_1831) was not at all defective in $\mathrm{Fe}$ (II) oxidation (note that the Tbd_1831 gene replacement was confirmed by PCR analysis of cells from the in vivo assay using Primers Tbd_1831-1 and Tbd_1831-6 and sequencing of the amplicon). Thus, the question arises: how is the NADH that is oxidized in complex I actually produced during $\mathrm{Fe}$ (II) oxidation? It is possible, but speculative, that reverse electron transfer in T. denitrificans is routed through a protein complex other than complex III (see below). It is also possible that another $c$-type cytochrome is upregulated in the Tbd_1831 mutant and is compensating for Tbd_1831's role in complex III. However, a BLASTP search of the $T$. denitrificans genome reveals that there is no protein encoded by the genome that matches Tbd_1831 even at a low-stringency E-value of $10^{-2}$. Another possibility is that reverse electron transfer indeed functions via complex III in T. denitrificans but that the $c_{1}$-cytochrome subunit is not essential for this process. Finally, it is not plausible that $\mathrm{H}_{2}$ oxidation could be contributing to reduction of the quinone pool, as nitrate-dependent $\mathrm{Fe}$ (II) oxidation takes place in the absence of $\mathrm{H}_{2}$ (Figure 1B) and the rate of $\mathrm{Fe}$ (II) oxidation in the nuoD (Tbd_1145) mutant in the absence of $\mathrm{H}_{2}$ is comparable to that in the presence of $\mathrm{H}_{2}$ (data not shown).

Regarding an alternate pathway for reverse electron transfer that does not involve complex III, it is possible that nitric oxide reductase (NorBC; Tbd_0561-Tbd_0562) could play the role that has been assigned to the cytochrome $b c_{1}$ complex. Like the cytochrome $b c_{1}$ complex, NorBC is a cytoplasmic-membrane complex that includes $b$ - and $c$-type cytochromes [with relatively high midpoint reduction potentials in NorBC of +345 and $+310 \mathrm{mV}$ for low-spin $b$ - and $c$ hemes, respectively (Watmough et al., 2009)]. Although, unlike the cytochrome $b c_{1}$ complex and qNOR nitric oxide reductases (de Vries et al., 2003; Tavares et al., 2006), NorBC is not thought to interact directly with the quinone pool, electron transfer interactions between nitric oxide reductase and the ubiquinone pool through a mediator have been suggested for other bacteria (Bell et al., 1992). Considering that mechanistic knowledge of reverse electron transfer in chemolithotrophic bacteria is currently quite limited, exploration of alternatives to complex III in a genetically tractable organism, such as T. denitrificans, could substantially improve understanding of this fundamental physiological process.

The above discussion and finding that a mutant in the $c_{1^{-}}$cytochrome subunit of the cytochrome $b c_{1}$ complex was not defective in $\mathrm{Fe}(\mathrm{II})$ oxidation is relevant to a recently postulated mechanism for nitrate-dependent Fe(II) oxidation (Carlson et al., 2012), namely, electron transfer from $\mathrm{Fe}(\mathrm{II})$ to the quinone pool mediated by the cytochrome $b c_{1}$ complex. Our results for the Tbd_1831 mutant are not consistent with this hypothesized mechanism. Further study will be required to address the role of complex III in reverse electron transfer in T. denitrificans and to elucidate the enzyme(s) that initiate the process of nitrate-dependent $\mathrm{Fe}(\mathrm{II})$ oxidation in this and other bacterial species.

\section{AUTHOR CONTRIBUTIONS}

Harry R. Beller was the primary author, conceived of the overall study, and designed and participated in the microarray experiments. Peng Zhou created all replacement mutants, conducted the entire transposon mutagenesis study, and performed all Fe(II) oxidation assays. Harry R. Beller and Peng Zhou contributed equally to the manuscript. Tina C. Legler created all insertion mutants and participated in microarray studies along with Staci Kane and Tracy E. Letain. Anu Chakicherla performed statistical analyses of microarray studies. Peggy A. O’Day provided geochemical input. 


\section{ACKNOWLEDGMENTS}

We thank Steven Singer (LBNL) for providing helpful comments on the manuscript. This work was supported as part of the Subsurface Biogeochemical Research Scientific Focus Area funded by the U.S. Department of Energy, Office of Science, Office of Biological and Environmental Research under Award Number DEAC02-05CH11231 (LBNL) and DOE-SBR DE-SC0005479 (U.C. Merced).

\section{REFERENCES}

Altschul, S. F., Madden, T. L., Schaffer, A. A., Zhang, J., Zhang, Z., Miller, W., etal. (1997). Gapped BLAST and PSI-BLAST: a new generation of protein database search programs. Nucleic Acids Res. 25, 3389-3402. doi: 10.1093/nar/25.17.3389

Bell, L. C., Richardson, D. J., and Ferguson, S. J. (1992). Identification of nitric oxide reductase activity in Rhodobacter capsulatus: the electron transport pathway can either use or bypass both cytochrome $c_{2}$ and the cytochrome $b c_{1}$ complex. J. Gen. Microbiol. 138, 437-443. doi: 10.1099/00221287-138-3-437

Beller, H. R. (2005). Anaerobic, nitrate-dependent oxidation of U(IV) oxide minerals by the chemolithoautotrophic bacterium Thiobacillus denitrificans. Appl. Environ. Microbiol. 71, 2170-2174. doi: 10.1128/AEM.71.4.2170-2174. 2005

Beller, H. R., Chain, P. S., Letain, T. E., Chakicherla, A., Larimer, F. W., Richardson, P. M., et al. (2006a). The genome sequence of the obligately chemolithoautotrophic, facultatively anaerobic bacterium Thiobacillus denitrificans. J. Bacteriol. 188, 14731488. doi: 10.1128/JB.188.4.14731488.2006

Beller, H. R., Letain, T. E., Chakicherla, A., Kane, S. R., Legler, T. C., and Coleman, M. A. (2006b). Whole-genome transcriptional analysis of chemolithoautotrophic thiosulfate oxidation by Thiobacillus denitrificans under aerobic versus denitrifying conditions. J. Bacteriol. 188, 7005-7015. doi: 10.1128/JB.00568-06

Beller, H. R., Han, R., Karaoz, U., Lim, H., and Brodie, E. L. (2013). Genomic and physiological characterization of the chromate-reducing, aquiferderived Firmicute Pelosinus sp. strain HCF1. Appl. Environ. Microbiol. 79, 63-73. doi: 10.1128/AEM.02496-12

Beller, H. R., Legler, T. C., Bourguet, F., Letain, T. E., Kane, S. R., and Coleman, M. A. (2009). Identification of $c$-type cytochromes involved in anaerobic, bacterial U(IV) oxidation. Biodegradation 20, 45-53. doi: 10.1007/s10532-008-9198-y

Beller, H. R., Legler, T. C., and Kane, S. R. (2012). "Genetic manipulation of the obligate chemolithoautotrophic bacterium Thiobacillus denitrificans," in Microbial Systems Biology: Methods and Protocols, ed. A. Navid (New York: Springer Science), 99-136. doi: 10.1007/978-1-61779-827-6_5.

Berks, B. C., Page, M. D., Richardson, D. J., Reilly, A., Cavill, A., Outen, F., et al. (1995). Sequence analysis of subunits of the membrane-bound nitrate reductase from a denitrifying bacterium: the integral membrane subunit provides a prototype for the dihaem electron-carrying arm of a redox loop. Mol. Microbiol. 15, 319-331. doi: 10.1111/j.13652958.1995.tb02246.x

Bird, L. J., Bonnefoy, V., and Newman, D. K. (2011). Bioenergetic challenges of microbial iron metabolisms. Trends Microbiol. 19, 330-340. doi: 10.1016/j.tim.2011.05.001

Bolstad, B. M., Irizarry, R. A., Astrand, M., and Speed, T. P. (2003). A comparison of normalization methods for high density oligonucleotide array data based on variance and bias. Bioinformatics 19, 185-193. doi: 10.1093/bioinformatics/19.2. 185

Carlson, H. K., Clark, I. C., Melnyk, R. A., and Coates, J. D. (2012). Toward a mechanistic understanding of anaerobic nitrate-dependent iron oxidation: balancing electron uptake and detoxification. Front. Microbiol. 3:57. doi: 10.3389/fmicb.2012. 00057

Castelle, C., Guiral, M., Malarte, G., Ledgham, F., Leroy, G., Brugna, M., et al. (2008). A new iron-oxidizing $/ \mathrm{O}_{2}$-reducing supercomplex spanning both inner and outer membranes, isolated from the extreme acidophile Acidithiobacillus ferrooxidans. J. Biol. Chem. 283, 25803-25811. doi: 10.1074/jbc.M802496200

Croal, L. R., Jiao, Y., and Newman, D. K. (2007). The fox operon from Rhodobacter strain SW2 promotes phototrophic $\mathrm{Fe}$ (II) oxidation in Rhodobacter capsulatus SB1003. J. Bacteriol. 189, 1774-1782. doi: 10.1128/JB.01395-06

de Vries, S., Strampraad, M. J., Lu, S. Moenne-Loccoz, P., and Schroder, I. (2003). Purification and characterization of the $\mathrm{MQH}_{2}$ :NO oxidoreductase from the hyperthermophilic archaeon Pyrobaculum aerophilum. J. Biol. Chem. 278, 35861-35868. doi: 10.1074/jbc.M300857200

Finneran, K. T., Housewright, M. E., and Lovley, D. R. (2002).
Multiple influences of nitrate on uranium solubility during bioremediation of uranium-contaminated subsurface sediments. Environ. Microbiol. 4, 510-516. doi: 10.1046/ j.1462-2920.2002.00317.x

Fredrickson, J. K., Zachara, J. M. Kennedy, D. W., Duff, M. C., Gorby, Y. A., Li, S. M. W., et al. (2000). Reduction of $\mathrm{U}(\mathrm{VI})$ in goethite (alpha-FeOOH) suspensions by a dissimilatory metal-reducing bacterium. Geochim. Cosmochim. Acto 64, 3085-3098. doi: 10.1016/S00167037(00)00397-5

Ginder-Vogel, M., Criddle, C. S., and Fendorf, S. (2006). Thermodynamic constraints on the oxidation of biogenic $\mathrm{UO}_{2}$ by $\mathrm{Fe}(\mathrm{III})$ (hydr)oxides. Environ. Sci. Technol. 40, 3544-3550. doi: 10.1021/es052305p

Hafenbradl, D., Keller, M., Dirmeier, R., Rachel, R., Rossnagel, P., Burggraf, S., et al. (1996). Ferroglobus placidus gen. nov., sp. nov., A novel hyperthermophilic archaeum that oxidizes $\mathrm{Fe}^{(2+)}$ at neutral $\mathrm{pH}$ under anoxic conditions. Arch. Microbiol. 166, 308-314. doi: 10.1007/s0020300 50388

Han, R., Geller, J. T., Yang, L., Brodie, E. L., Chakraborty, R., Larsen, J. T., et al. (2010). Physiological and transcriptional studies of $\mathrm{Cr}(\mathrm{VI})$ reduction under aerobic and denitrifying conditions by an aquiferderived pseudomonad. Environ. Sci. Technol. 44, 7491-7497. doi: 10.1021/ es101152r

Hedrich, S., Schlomann, M., and Johnson, D. B. (2011). The ironoxidizing proteobacteria. Microbiology 157, 1551-1564. doi: 10.1099/ mic.0.045344-0

Ilbert, M., and Bonnefoy, V. (2013). Insight into the evolution of the iron oxidation pathways. Biochim. Biophys. Acta 1827, 161-175. doi: 10.1016/j.bbabio.2012.10.001

Jiao, Y., and Newman, D. K. (2007) The pio operon is essential for phototrophic $\mathrm{Fe}(\mathrm{II})$ oxidation in Rhodopseudomonas palustris TIE-1. J. Bacteriol. 189, 1765-1773. doi: 10.1128/JB.00776-06

Kopf, S. H., Henny, C., and Newman, D. K. (2013). Ligand-enhanced abiotic iron oxidation and the effects of chemical versus biological iron cycling in anoxic environments. Environ. Sci. Technol. 47, 2602-2611. doi: 10.1021/es3049459
Letain, T. E., Kane, S. R., Legler, T. C., Salazar, E. P., Agron, P. G., and Beller, H. R. (2007). Development of a genetic system for the chemolithoautotrophic bacterium Thiobacillus denitrificans. Appl. Environ. Microbiol. 73, 32653271. doi: 10.1128/AEM.02928-06

Liu, J., Wang, Z., Belchik, S. M., Edwards, M. J., Liu, C., Kennedy, D. W., etal. (2012). Identification and characterization of MtoA: a decaheme $c$-type cytochrome of the neutrophilic $\mathrm{Fe}(\mathrm{II})$-oxidizing bacterium Sideroxydans lithotrophicus ES-1. Front. Microbiol. 3:37. doi: 10.3389/fmicb.2012.00037

Lloyd, J. R., Leang, C., Hodges Myerson, A. L., Coppi, M. V., Cuifo, S., Methe, B., et al. (2003). Biochemical and genetic characterization of PpcA, a periplasmic c-type cytochrome in Geobacter sulfurreducens. Biochem. J. 369, 153-161. doi: 10.1042/BJ20020597

Lovley, D. R., and Phillips, E. J. P. (1992a). Bioremediation of uranium contamination with enzymatic uranium reduction. Environ. Sci. Technol. 26, 2228-2234. doi: 10.1021/es00035a023

Lovley, D. R., and Phillips, E. J. P. (1992b). Reduction of uranium by Desulfovibrio desulfuricans. Appl. Environ. Microbiol. 58, 850-856.

Lovley, D. R., Phillips, E. J. P., Gorby, Y. A., and Landa, E. R. (1991). Microbial reduction of uranium. Nature 350 , 413-416. doi: 10.1038/350413a0

Lovley, D. R., Widman, P. K., Woodward, J. C., and Phillips, E. J. P. (1993). Reduction of uranium by cytochrome- $c_{3}$ of Desulfovibrio vulgaris. Appl. Environ. Microbiol. 59, 3572-3576.

Murphy, K. C., Campellone, K. G., and Poteete, A. R. (2000). PCR-mediated gene replacement in Escherichia coli. Gene 246, 321330. doi: 10.1016/S0378-1119(00) 00071-8

Picardal, F. (2012). Abiotic and microbial interactions during anaerobic transformations of $\mathrm{Fe}(\mathrm{II})$ and $\mathrm{NO}_{\mathrm{x}}^{-}$. Front. Microbiol. 3:112. doi: 10.3389/fmicb.2012.00112

Preis, W., and Gamsjager, H. (2002). Critical evaluation of solubility data: enthalpy of formation of siderite. Phys. Chem. Chem. Phys. 4, 40144019. doi: 10.1039/b203626f 
Richardson, D. J. (2000). Bacterial respiration: a flexible process for a changing environment. Microbiology 146(Pt 3), 551-571.

Riley, R. G., and Zachara, J. M. (1992). Nature of Chemical Contamination on DOE Lands and Identification of Representative Contaminant Mixtures for Basic Subsurface Science Research. Washington, DC: Office of Energy Research, Subsurface Science Program, U.S. Department of Energy.

Roden, E. E. (2012). Microbial ironredox cycling in subsurface environments. Biochem. Soc. Trans. 40, 1249 1256. doi: 10.1042/BST20120202

Sani, R. K., Peyton, B. M., Dohnalkova, A., and Amonette, J. E. (2005). Reoxidation of reduced uranium with iron(III) (hydr)oxides under sulfate-reducing conditions. Environ. Sci. Technol. 39, 2059-2066. doi: 10.1021/es0494297

Saraiva, I. H., Newman, D. K., and Louro, R. O. (2012). Functional characterization of the FoxE iron oxidoreductase from the photoferrotroph Rhodobacter ferrooxidans SW2. J. Biol. Chem. 287, 25541-25548. doi: 10.1074/jbc.M112.360636

Senko, J. M., Istok, J. D., Suflita, J. M., and Krumholz, L. R. (2002). In-situ evidence for uranium immobilization and remobilization. Environ. Sci. Technol. 36, 1491-1496. doi: 10.1021/es011240x

Senko, J. M., Kelly, S. D., Dohnalkova, A. C., Mcdonough, J. T., Kemner, K. M., and Burgos, W. D. (2007). The effect of $\mathrm{U}(\mathrm{VI})$ bioreduction kinetics on subsequent reoxidation of biogenic U(IV). Geochim. Cosmochim. Acta 71, 4644-4654. doi: 10.1016/j.gca.2007.07.021

Senko, J. M., Mohamed, Y., Dewers, T. A., and Krumholz, L. R. (2005a). Role for Fe(III) minerals in nitrate-dependent microbial U(IV) oxidation. Environ. Sci. Technol. 39, 2529-2536. doi: 10.1021/es048906i

Senko, J. M., Suflita, J. M., and Krumholz, L. R. (2005b). Geochemical controls on microbial nitrate-dependent U(IV) oxidation. Geomicrobiol. J. 22, 371-378. doi: $10.1080 / 01490450500248911$

Singer, E., Emerson, D., Webb, E. A. Barco, R. A., Kuenen, J. G., Nelson, W. C., et al. (2011). Mariprofundus ferrooxydans PV-1 the first genome of a marine $\mathrm{Fe}(\mathrm{II})$ oxidizing Zetaproteobacterium. PLoS ONE 6:e25386. doi: 10.1371/journal.pone. 0025386

Smyth, G. K. (2005). "Limma: linear models for microarray data," in Bioinformatics and Computational Biology Solutions using $R$ and Bioconductor eds R. Gentleman, V. Carey, S. Diudoit, R. Irizarry, and W. Huber (New York: Springer), 473.

Straub, K. L., Benz, M., Schink, B., and Widdel, F. (1996). Anaerobic nitrate-dependent microbial oxidation of ferrous iron. Appl. Environ. Microbiol. 62, 1458-1460.

Tavares, P., Pereira, A. S., Moura, J. J., and Moura, I. (2006). Metalloenzymes of the denitrification pathway. J. Inorg. Biochem. 100, 2087-2100. doi: 10.1016/j.jinorgbio.2006.09.003

Thauer, R. K., Jungermann, K. and Decker, K. (1977). Energyconservation in chemotropic anaerobic bacteria. Bacteriol. Rev. 41, 100-180.

Tokunaga, T. K., Wan, J. M., Kim, Y. M., Sutton, S. R., Newville, M., Lanzirotti, A., et al. (2008). Realtime X-ray absorption spectroscopy of uranium, iron, and manganese in contaminated sediments during bioreduction. Environ. Sci. Technol. 42, 2839-2844. doi: 10.1021/es70 $2364 \mathrm{x}$
U.S. Environmental Protection Agency (1999). MINTEQA2/PRODEFA2, A Geochemical Assessment Model for Environmental Systems: User Manual Supplement for Version 4.0. Washington, DC: U.S. Environmental Protection Agency.

Wan, J. M., Tokunaga, T. K., Brodie, E., Wang, Z. M., Zheng, Z. P., Herman, D., et al. (2005). Reoxidation of bioreduced uranium under reducing conditions. Environ. Sci. Technol.39, 6162-6169. doi: 10.1021/ es048236g

Watmough, N. J., Field, S. J., Hughes, R. J., and Richardson, D. J. (2009). The bacterial respiratory nitric oxide reductase. Biochem. Soc. Trans. 37, 392-399. doi: 10.1042/ BST0370392

Weber, K. A., Achenbach, L. A., and Coates, J. D. (2006a). Microorganisms pumping iron: anaerobic microbial iron oxidation and reduction. Nat. Rev. Microbiol. 4, 752-764. doi: 10.1038/nrmicro 1490

Weber, K. A., Hedrick, D. B. Peacock, A. D., Thrash, J. C., White, D. C., Achenbach, L. A., et al. (2009). Physiological and taxonomic description of the novel autotrophic, metal oxidizing bacterium, Pseudogulbenkiania sp. strain 2002. Appl. Microbiol. Biotechnol. 83, 555-565. doi: 10.1007/s00253-0091934-7

Weber, K. A., Pollock, J., Cole, K. A., O’Connor, S. M., Achenbach, L. A., and Coates, J. D. (2006b). Anaerobic nitrate-dependent iron(II) biooxidation by a novel lithoautotrophic betaproteobacterium, strain 2002 . Appl. Environ. Microbiol. 72, 686694. doi: 10.1128/AEM.72.1.686694.2006

$\mathrm{Xu}, \mathrm{T}$, Spycher, N., Sonnenthal, E. L., Zhang, G., Zheng, L., and
Pruess, K. (2011). TOUGHREACT Version 2.0: a simulator for subsurface reactive transport under non-isothermal multiphase flow conditions. Comput. Geosci. 37, 763-774. doi: 10.1016/j.cageo.2010. 10.007

Zumft, W. G. (1997). Cell biology and molecular basis of denitrification. Microbiol. Mol. Biol. Rev. 61, 533616.

Conflict of Interest Statement: The authors declare that the research was conducted in the absence of any commercial or financial relationships that could be construed as a potential conflict of interest.

Received: 13 May 2013; paper pending published: 20 June 2013; accepted: 06 August 2013; published online: 27 August 2013.

Citation: Beller HR, Zhou P, Legler TC, Chakicherla A, Kane S, Letain TE and O'Day PA (2013) Genome-enabled studies of anaerobic, nitrate-dependent iron oxidation in the chemolithoautotrophic bacterium Thiobacillus denitrificans. Front. Microbiol. 4:249. doi: 10.3389/fmicb.2013.00249

This article was submitted to Microbial Physiology and Metabolism, a section of the journal Frontiers in Microbiology. Copyright (c) 2013 Beller, Zhou, Legler, Chakicherla, Kane, Letain and O'Day. This is an open-access article distributed under the terms of the Creative Commons Attribution License (CC BY). The use, distribution or reproduction in other forums is permitted, provided the original author(s) or licensor are credited and that the original publication in this journal is cited, in accordance with accepted academic practice. No use, distribution or reproduction is permitted which does not comply with these terms. 